\title{
Hepatic Overexpression of Bovine Scavenger Receptor Type I in Transgenic Mice Prevents Diet-induced Hyperbetalipoproteinemia
}

\author{
Sabine Wölle, * David P. Via, „ Lawrence Chan, Joseph A. Cornicelli, * and Charles L. Bisgaier* \\ * Department of Atherosclerosis Therapeutics, Parke-Davis Pharmaceutical Research, Division of Warner Lambert Company, Ann Arbor, \\ Michigan 48105; ${ }^{\ddagger}$ Department of Medicine and the Methodist Hospital, Baylor College of Medicine, Houston, Texas 77030; and \\ Department of Cell Biology, Baylor College of Medicine, Houston, Texas 77030
}

\begin{abstract}
Hepatic scavenger receptors (SR) may play a protective role by clearing modified lipoproteins before they target the artery wall. To gain insight into this hypothesized function, transgenic mice expressing hepatic bovine SR (TgSR) were created and studied when fed chow, and during diet-induced hyperlipidemia. SR overexpression resulted in extensive hepatic parenchymal cell uptake of fluorescently labeled acetylated human low density lipoprotein (DiI ac-hLDL) and a twofold increase in ${ }^{125}$ I-acetylated-LDL clearance. Food intake and cholesterol absorption was indistinguishable between control and TgSR mice. In chow-fed mice, lipoprotein cholesterol was similar in control and TgSR mice. However, on a 3-wk high fat/cholesterol (HFHC) diet, the rise in apoB containing lipoproteins was suppressed in $\mathrm{TgSR}+/-$ and TgSR $+/+$ mice. The rise in HDL was similar in control and TgSR $+/-$ mice, but significantly elevated in the TgSR $+/+$ mice. Overall, on chow, the ratio of apo-B containing lipoprotein cholesterol to HDL cholesterol was similar for all groups (control $=0.33 ; \mathrm{TgSR}+I-=0.32 ; \mathrm{TgSR}+/+$ $=0.38$ ). However, after 3 wk on the HFHC diet, this ratio was markedly higher in control $(2.34 \pm 0.21)$ than in either $\mathrm{TgSR}+/-(1.00 \pm 0.24)$ or $\mathrm{TgSR}+/+(1.00 \pm 0.19)$ mice. In TgSR+/- mice, hepatic cholesteryl esters were reduced by $59 \%, 7 \alpha$-hydroxylase mRNA levels were elevated twofold, and a significant increase in fecal bile acid flux was observed after the 3-wk HFHC diet. These results suggest SR may play a protective role in liver by preventing diet-induced increases in apoB containing lipoproteins. ( $J$. Clin. Invest. 1995. 96:260-272.) Key words: minigene - lipoprotein profile $\bullet$ transgenic mice $\bullet$ hepatic lipids $\bullet$ apoB containing lipoprotein/HDL ratio
\end{abstract}

\section{Introduction}

The macrophage is thought to play a pivotal role in the pathogenesis of atherosclerosis (1-8). Scavenger receptors (SR) ${ }^{1}$

Address correspondence to Charles L. Bisgaier, Ph.D., Atherosclerosis Therapeutics, Parke-Davis Pharmaceutical Research, 2800 Plymouth Road, Ann Arbor, MI 48105. Phone: 313-996-2726; FAX: 313-9985707; E-Mail: BISGAIC@aa.wl.com

Received for publication 10 October 1994 and accepted in revised form 20 March 1995.

J. Clin. Invest.

(C) The American Society for Clinical Investigation, Inc. 0021-9738/95/07/0260/13 \$2.00

Volume 96, July 1995, 260-272 are present on macrophages and mediate binding and internalization of a broad variety of ligands including modified apoB containing lipoproteins (1-26). SR activity may also be present on smooth muscle, fibroblasts and endothelial cells under specific circumstances (27-29). Unlike the LDL receptor, the SR lacks negative feedback regulation by cholesterol allowing the sustained uptake of modified lipoprotein and transformation of macrophages into foam cells (1-3). The macrophage-derived foam cell is characteristic of early lesions in a variety of species including humans; its accelerated formation can be mimicked in a variety of animal models fed cholesterol-enriched diets $(30,31)$

Two forms of bovine SR, type I and type II, have been cloned from bovine lung libraries $(32,33)$. These trimeric structurally similar receptors are derived from alternative splicing of a single gene product resulting in SR that contain (type I) or lack (type II) the carboxyl terminal cysteine-rich domain (34). Although the cysteine-rich domain (i.e., type I, domain VI) is highly conserved between species its functional significance is not known. Mutagenesis studies of Acton et al. (35) suggest the collagenous domain (domain $\mathrm{V}$ ) present in both type I and II SR contain the sequence necessary for recognition of polyanionic ligands. Structural studies of Penman et al. (36) have suggested that the assembly of SR into trimers involves the noncovalent association of a spacer domain (i.e., domain III) disulfide linked dimer with a monomer. The trimeric SR structure, however, does not appear to be requisite for functional binding since monomers are fully capable of binding ligands (37).

Although overwhelming circumstantial evidence suggests modified LDL exists in vivo (5), their presence has been viewed with skepticism since these particles have not been isolated from plasma. It is likely their compartmentalized formation in the subendothelium and rapid uptake by resident macrophages prevent any accumulation in plasma. However, in vitro and in vivo, macrophage SR avidly bind, internalize and degrade chemically modified LDL. Although smooth muscle cell and macrophage scavenger receptor expression may play a role in lesion formation, their presence in liver may portend a protective role (6). Indeed, nonparenchymal cells, including Kupffer and endothelial cells are capable of binding and degradation of acetylated and oxidized LDL $(12,38-40)$. Furthermore,

1. Abbreviations used in this paper: Ac-hLDL, acetylated human LDL; DiI, 1,1'-dioctadecyl-3,3,3',3'-tetramethylindocarbocyanine perchlorate; HFHC, high fat high cholesterol diet; HPLC, high pressure liquid chromatography; SR, scavenger receptors; $\mathrm{Tg}$, transgenic. 
intravenously infused acetylated LDL accumulates primarily in hepatic sinusoidal and endothelial cells, and to a lesser extent in Kupffer cells $(12,39,41-44)$. Studies utilizing oxidized LDL have instead primarily demonstrated ligand accumulation in Kupffer, and to a lesser extent in endothelial cells (45). Acetylated LDL uptake by hepatic parenchyma occurs at a near negligible rate (41). Overall, these studies suggest that liver nonparenchymal cells have the capacity to remove potentially atherogenic lipoproteins.

To directly determine whether or not hepatic SR have a protective anti-atherosclerotic role, transgenic mice overexpressing hepatic bovine SR type I were created in the genetic background of the FVB mouse crossed to the atherosclerosissusceptible C57BL/6J mouse. Both heterozygous (TgSR +/-) and homozygous $(\mathrm{TgSR}+/+$ ) mice were created. Uptake of modified lipoproteins was greatly enhanced in the liver of these animals. Furthermore, when fed cholesterol-enriched diets, these mice present with marked reductions in apoB-containing lipoproteins and hepatic cholesteryl esters, and increased hepatic $7 \alpha$-hydroxylase mRNA levels and total fecal bile acids. These data directly demonstrate a potential in vivo anti-atherosclerotic role of hepatic SR.

\section{Methods}

Bovine SR minigene preparation. A partial SR type I cDNA clone was isolated from a bovine lung $\lambda$ gt 10 cDNA library (Clontech Laboratories, Inc., Palo Alto, CA) using three oligonucleotides that were selected based on the published sequence (32). This cDNA fragment, $1.8 \mathrm{~kb}$ in length, was subcloned into pGEM 3Zf (-) (Promega Corp., Madison, WI). The missing $0.3 \mathrm{~kb}$ of the $5^{\prime}$ end of the partial cDNA clone was synthesized by coupled reverse transcriptase and polymerase chain reaction (PCR) $(46,47)$ using bovine lung mRNA (Clontech Laboratories, Inc.) as a template and the specific 5' (5'-GGGCGTCCGGATTTGGAGATATATCTGCA-3') and 3' (5'-GCGGATCCGAAGTATGGCACGTGGGATGACTTTCC-3') primers. This generated cDNA fragment was then ligated into the pGEM 3Zf (-) plasmid (Promega Corp., Madison, WI) that contained $1.8 \mathrm{~kb}$ of bovine SR between BamHI in the vector polylinker site and the SR sequence internal AccIII restriction site. The full-length bovine SR cDNA was verified (32) by nucleotide sequencing using the dideoxy-chain termination method (48). To construct the bovine SR minigene, $3 \mathrm{~kb}$ of the mouse transferrin promoter (49) were ligated to the $5^{\prime}$ end of the bovine SR cDNA. The mouse transferrin promoter contained an artificially introduced BamHI restriction site (49) at the $3^{\prime}$ end which was convenient for ligation to the bovine SR clone. The resulting construct contained 5 bp of the $5^{\prime}$ untranslated region of the bovine SR upstream of the ATG start site. Inclusion of this short 5-bp untranslated region in the construct appears to be necessary for efficient translation (i.e., "first AUG rule") (50, 51 ). At the $3^{\prime}$ end of the promoter-bovine SR construct, $0.65 \mathrm{~kb}$ of the human growth hormone gene containing the sequence for the poly-A signal were ligated at an Asp700/SmaI fusion site (Fig. 1). The total size of the minigene construct was $5.2 \mathrm{~kb}$ and was isolated by cutting with EcoRI (5' end) and NotI ( $3^{\prime}$ end), purified with Qiaex (Qiagen Inc., Chatsworth, CA) and utilized for production of transgenic mice.

Production of bovine SR transgenic mice. Fertilized one-cell embryos were isolated from superovulated C57BL/6J $\times$ FVB mice (Jackson Laboratories). To create transgenic mice, approximately one thousand male pronuclei of the fertilized embryos were microinjected with the purified 5.2-kb minigene construct described above at a DNA concentration of $3 \mathrm{ng} / \mathrm{ml}(52,53)$ and reimplanted into ICR pseudopregnant mice. 45 potential founders were screened by Southern blotting and PCR (see below). Of these, three mice were positive and therefore breed to C57BL/6J mates. Of the three founders, only one female mouse (mouse No.1876) incorporated the transgene in the germline and passed it on to offspring; the other two potential founders were chimerics. A heterozygous line ( $\mathrm{TgSR}+/-)$ was established by breeding mouse No. 1876 to nontransgenic C57BL/6J mice. Homozygous mice $(\mathrm{TgSR}+/+)$ were obtained by crossing $\mathrm{TgSR}+/-$. The TgSR $+1-$ mice appeared healthy and thrived for at least 2 years and the $\mathrm{TgSR}+/+$ have been healthy since their creation $(\sim 0.8 \mathrm{yr})$.

Bovine SR minigene transmission in founder and offspring generations was confirmed by both Southern blot analysis (54) and PCR. For Southern blot analysis, genomic DNA $(10 \mu \mathrm{g})$ was digested with restriction enzymes EcoRI and BamHI or BamHI alone. The samples were electrophoresed in a $1 \%$ agarose gel and blotted onto Zetaprobe membranes (Bio-Rad Laboratories, Hercules, CA). Blots were prehybridized for $5-6 \mathrm{~h}$ at $42^{\circ} \mathrm{C}$, and then hybridized overnight to a $0.7-\mathrm{kb}$ fragment (see Fig. 1) that was random primed (Boehringer Mannheim, Indianapolis, IN) using $\alpha-{ }^{32} \mathrm{P}$ dCTP (Amersham Corp., Arlington Heights, IL). By PCR analysis, using the bovine specific primers $5^{\prime}$ CCTCCATCCAGGAACATGAG-3' and 5'-CCTTTTCTGTGGATAAAATTC-3', a 1-kb cDNA fragment could be amplified from transgenic mice but not from nontransgenic littermates.

Southern blot analysis was used to estimate transgene copy number. TgSR + / - genomic DNA hybridization intensities were compared to standards comprised of control mouse genomic DNA containing variable amounts of the bovine SR minigene DNA.

$R N A$ analysis. Tissue specific expression of bovine SR, mouse $7 \alpha-$ hydroxylase, and mouse actin (Ambion, Inc., Austin, TX) mRNA were determined by Northern blot analysis. Total RNA was isolated from liver, spleen, lung, brain, heart, kidney, small intestine, large intestine, ovary, adipose, and muscle from control and transgenic mice with RNAzol (Biotecx Laboratories, Inc., Houston', TX) according to instructions supplied with reagent. Quantitative and qualitative assessment of total RNA were determined spectrophotometrically and on $1 \%$ analytical agarose gels, respectively.

Before performing Northern blot analysis total liver RNA (5 $\mu \mathrm{g}$ ) from $\mathrm{TgSR}+1-$ and nontransgenic littermates were used for reverse transcriptase reactions using the upstream specific bovine SR primer ( $5^{\prime}$-CCTTTTCTGTGGATAAAATTC- ${ }^{\prime}$ ') and a first strand cDNA synthesis kit (Superscript, BRL). A control reaction without the reverse transcriptase enzyme (Seikagaku America, Inc.) was performed. The reaction proceeded for $15 \mathrm{~min}$ at $37^{\circ} \mathrm{C}$, and then at $42^{\circ} \mathrm{C}$ for an additional $30 \mathrm{~min}$. The reverse transcriptase product, was subject to PCR amplification in the presence of the down stream primer ( $5^{\prime}$-CCTCCATCCAGGAACATGAG-3') and a PCR amplification kit (Perkin-Elmer). The product was analyzed on a $1 \%$ agarose gel.

For Northern analysis, samples (10 $\mu \mathrm{g}$ total RNA) were heated at $70^{\circ} \mathrm{C}$ for $10 \mathrm{~min}$ in loading buffer (DEPC water, $1 \times$ MOPS, 6.6\% formaldehyde, $50 \%$ formamide, $5 \%$ glycerol, bromphenol blue) and then separated by $6.3 \%$ formaldehyde- $1 \%$ agarose gel electrophoresis. RNA was transferred onto Zetaprobe membranes in 10× SSC buffer and hybridized to the random primed $0.7-\mathrm{kb}^{32} \mathrm{P}$-bovine SR cDNA probe described above (Fig. 1) at $65^{\circ} \mathrm{C}$. Blots were first washed with $0.1 \times$ $\mathrm{SSC} / 0.1 \% \mathrm{SDS}$ at room temperature for $10 \mathrm{~min}$, and then at $50^{\circ} \mathrm{C}$ for additional $10 \mathrm{~min}$. Blots were exposed to X-Omat AR film (Eastman Kodak Co., Rochester, NY). In a separate Northern blot experiment it was shown that the ${ }^{32} \mathrm{P}$-bovine SR cDNA probe does not recognize the endogenous mouse SR; similarly, a $0.2-\mathrm{kb}^{32} \mathrm{P}$-mouse SR cDNA probe was shown to be specific for the mouse SR. To estimate hepatic bovine SR relative abundance to that of the endogenous mouse SR mRNA, duplicate Northern blots of hepatic mRNA from control and TgSR+/mice were hybridized to either the mouse or bovine specific SR CDNA probe and processed in a similar fashion as above.

Northern blot analysis was also used to quantitate endogenous hepatic $7 \alpha$-hydroxylase and actin mRNA levels in control and TgSR $+1-$ mice fed the HFHC diet. Total RNA from liver (10 $\mu \mathrm{g} / \mathrm{lane})$ was electrophoresed on duplicate formaldehyde gels and then transferred in 20x SSC buffer to duplicate nitrocellulose membranes (Schleicher \& Schuell, Inc., Keene, NH). The membranes were baked for $1.5 \mathrm{~h}$ at 
$80^{\circ} \mathrm{C}$, prehybridized, and then hybridized at $62^{\circ} \mathrm{C}$ using formamide conditions with either a $0.3-\mathrm{kb}$ mouse $7 \alpha$-hydroxylase or mouse actin riboprobe generated using a run off kit (Riboprobe Gemini II Core System, Promega) and ${ }^{32} \mathrm{P}$-CTP (Amersham). The membranes were subject to three 10 -min $2 \times \mathrm{SSC} / 0.2 \%$ SDS washes, first at $40^{\circ} \mathrm{C}$, then at $50^{\circ} \mathrm{C}$, and then at $62^{\circ} \mathrm{C}\left(7 \alpha\right.$-hydroxylase ) or $50^{\circ} \mathrm{C}$ (actin). For $7 \alpha$-hydroxylase, two additional washes continued at $65^{\circ} \mathrm{C}$ in $0.1 \times \mathrm{SSC} / 0.2 \%$ SDS for $10 \mathrm{~min}$ and then for $20 \mathrm{~min}$. For actin, one additional wash continued at $50^{\circ} \mathrm{C}$ in $0.1 \times \mathrm{SSC} / 0.2 \%$ SDS for $10 \mathrm{~min}$. Image analysis and quantitation of Northern bands were determined on a Molecular Dynamics $400 \mathrm{E}$ Phosphoimager (Molecular Dynamics, Sunnyvale, CA).

Protein quantification. For different portions of these studies, protein was determined with either the BCA protein assay reagent (Pierce, Rockford, IL), by the method of Bradford (55) or Lowry et al. (56). In all cases bovine serum albumin was used as a standard.

Western blot analysis. Liver membranes were isolated from control and TgSR $+1-$ mice according to the method of Via et al (57). Briefly, livers were homogenized in $50 \mathrm{mM}$ Tris- $\mathrm{HCl}, 150 \mathrm{mM} \mathrm{NaCl}, 1 \mathrm{mM}$ EDTA, $0.5 \mathrm{mM}$ phenylmethylsulfonyl fluoride (PMSF) and $10 \mathrm{U} / \mathrm{ml}$ aprotinin, $\mathrm{pH} 8.0$ (4 ml/gram tissue), and spun at $1,500 \mathrm{~g}$ for $10 \mathrm{~min}$ at $4^{\circ} \mathrm{C}$ to remove cellular debris. Supernatants were centrifuged at $100,000 \mathrm{~g}\left(40,000 \mathrm{rpm}\right.$ in a Beckman Ti60 rotor) for $1 \mathrm{~h}$ at $4^{\circ} \mathrm{C}$, and membrane pellets were resuspended in ice-cold $40 \mathrm{mM}$ octyl $\beta$ glucopyranoside in $50 \mathrm{mM}$ Tris- $\mathrm{HCl}, 150 \mathrm{mM} \mathrm{NaCl}, 1 \mathrm{mM}$ EDTA, 0.5 $\mathrm{mM}$ PMSF, and $10 \mathrm{U} / \mathrm{ml}$ aprotinin, $\mathrm{pH}$ 8.0. Nonreduced membrane proteins were electrophoresed on $7.5 \%$ SDS polyacrylamide gels and transferred electrophoretically ( $100 \mathrm{~V}$ for $1.5 \mathrm{~h}$ at room temperature) to nitrocellulose membranes. Membranes were blocked with 5\% nonfat dried milk (blotto) in $50 \mathrm{mM}$ Tris- $\mathrm{HCl}, 150 \mathrm{mM} \mathrm{NaCl}, \mathrm{pH} \mathrm{8.0,} \mathrm{and}$ then incubated with rabbit anti-bovine SR IgG (a generous gift of Dr. Robert E. Pitas, The Gladstone Institute, San Francisco, CA). After incubation with goat anti-rabbit IgG conjugated to alkaline phosphatase, the bovine SR-antibody complexes were visualized with an ECL detection system (Amersham).

LDL isolation and modifications. Human LDL ( $\mathrm{hLDL})$ was isolated by sequential ultracentrifugation between the density intervals of 1.019$1.050 \mathrm{~g} / \mathrm{ml}(58)$. hLDL was acetylated with acetic anhydride (achLDL) (2) and used in fluorescence studies (see below). ac-hLDL was radiolabeled with ${ }^{125} \mathrm{I}$ by the iodine monochloride method of MacFarlane (59) and was used for kinetic studies (See below).

Fluorescence histochemistry. ac-hLDL was labeled with DiI according to the method of Voyta et al. (60). Control and TgSR $+/-$ mice were tail vein injected with DiI ac-hLDL $(320 \mu \mathrm{g}, 1.6 \mu \mathrm{g} / \mathrm{ml})$. After $10 \mathrm{~min}$, mice were sacrificed and liver tissue was rinsed in PBS and cut into pieces for embedding in OCT (Baxter) on dry ice. Cryostat sections $(3-5 \mathrm{~mm})$ were placed on polylysine coated slides and analyzed by fluorescence microscopy using a rhodamine filter set.

In vivo clearance of acetylated $L D L$. The kinetics of ${ }^{125} \mathrm{I}-\mathrm{ac}-\mathrm{hLDL}$ clearance in five $\mathrm{TgSR}+1-$ and five control mice was determined. Mice were tail vein injected with ${ }^{125} \mathrm{I}$-ac-hLDL $(1.6 \mathrm{mg}$ protein, $0.2 \mathrm{ml})$. Orbitalsinus blood samples $(10 \mu \mathrm{l})$ were collected periodically up to eight $\mathrm{min}$ in heparinized microcapillary tubes. Radioactivity data are expressed as percent of the first $20 \mathrm{~s}$ time point. To control for non-SR mediated ${ }^{125} \mathrm{I}$-ac-hLDL clearance, three $\mathrm{TgSR}+/-$ and three control mice were co-injected with $0.1 \mathrm{ml}$ of ${ }^{125} \mathrm{I}$-ac-hLDL preparation plus 0.1 $\mathrm{ml}$ Fucoidan $(10 \mathrm{mg} / \mathrm{ml})(1)$.

Food consumption studies. Five $\mathrm{TgSR}+/-$ and five control mice were maintained on a high fat high cholesterol (HFHC) diet (Diet D12336; Research Diets, Inc., New Brunswick, NJ) for 3 wk in individual metabolic cages. The HFHC diet was similar to the atherogenic diet used by Paigen et al. (61) and contained $1.25 \%$ cholesterol, $16 \%$ fat ( $5 \%$ soy bean oil, $7.5 \%$ cocoa butter, and $3.5 \%$ coconut oil), and $0.5 \%$ cholic acid. The selected animals had an average body weight of 22$25 \mathrm{~g}$ and were 2 mo old. Each group consisted of three males and two females. The weekly amounts of diet consumed by each animal was calculated at day 7,14 and 21 .

Feeding study. Five $\mathrm{TgSR}+/-$, four $\mathrm{TgSR}+/+$, and five control mice maintained on chow were fasted for 7-8 h before obtaining 0.3 $\mathrm{ml}$ blood from the tail while under Metofane (Pro-Vet) anesthesia. Mice were then put on the HFHC diet for 3 wk. Mice were bleed weekly after a $7-8 \mathrm{~h}$ fast.

Lipoprotein and lipid analysis. Lipoprotein total cholesterol distribution in $10 \mu \mathrm{l}$ plasma samples was determined continuously on-line in the post-column eluant following Superose 6 (Pharmacia Biotech Inc., Piscataway, NJ) high performance gel-filtration chromatography essentially as described $(62,63)$ except that we used a Rainin HPLC and Dynamax Compare software (Rainin Instrument Co., Inc., Woburn, MA) for instrumentation and data reduction, respectively. Total plasma triglycerides were determined with a commerically available kit (Triglicinet 2 kit; Sclavo Inc. Wayne, NJ). Total plasma cholesterols were determined according to the method of Allain et al. (64).

Plasma oxysterol analysis. Plasma from eight fasted $(8 \mathrm{~h})$ control and $10 \mathrm{TgSR}$ mice that were fed the high fat high cholesterol diet for 3 wk were used to determine oxysterol content by a slight modification of the gas chromatographic methods of Hodis et al. (65-67). Briefly, mouse plasmas $(25 \mu \mathrm{l})$ were extracted with $6 \mathrm{ml}$ of chloroform/methanol (2/1: vol/vol) containing $0.01 \%$ 2,6-di-tert-butyl-4-methyl-phenol

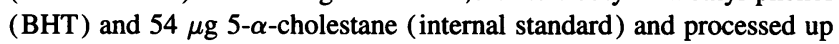
to the diazomethane derivatization step essentially as described (65). In lieu of diazomethane derivatization, samples were taken to dryness and dissolved in $N, N$-dimethylformamide (DMF) and derivatized with $N$-methyl- $N$-(t-butyldimethylsilyl) trifluroacetamide (MTBSTFA) containing $1 \%$ t-butyl-dimethylchlorosilane (BDMCS) (Regis Chemical Co., Morton Grove, IL) at $80^{\circ} \mathrm{C}$ for $1 \mathrm{~h}$. Samples were passed through Acrodisc 13 CR PTFE $0.45 \mathrm{mM}$ filters (Gelman Sciences, Ann Arbor, MI). Cholesterol, 5- $\alpha$-cholestane (Alltech Associates, Inc., Deerfield, IL.), and oxysterol standards of 5-cholesten-3 $\beta, 7 \alpha$-diol ( $7 \alpha$-hydroxycholesterol), 5-cholesten-3 $\beta, 7 \beta$-diol ( $7 \beta$-hydroxycholesterol), choles$\tan -5 \alpha, 6 \alpha$-epoxy-3 $\beta$-ol ( $\alpha$-epoxide), 3,5-cholestadien-7-one (3,5-diene ), cholestan- $3 \beta, 5 \alpha, 6 \beta$-triol (cholestane triol), 5-cholesten-3 $\beta, 25$-diol (25-hydroxycholesterol), 5-cholesten-3 $\beta$-ol-7-one (7-ketocholesterol) (Steraloids, Inc., Wilton, NH) and cholestan-5,6 $\beta$-epoxy-3 $\beta$-ol ( $\beta$-epoxy) (Research Plus, Inc., Bayonne, $\mathrm{NJ}$ ) were individually derivatized as above. Authentic standards, individually and combined in known proportions, reagent blanks, and mouse samples were separated on a RTX-1 (Restek, Bellefonte, PA) capillary column $(30 \mathrm{~mm} \times 0.53 \mathrm{~mm}$, $0.5 \mu \mathrm{m}$ film thickness) and quantitated using flame ionization detection on a Varian 3600 gas-liquid chromatograph. Data were collected and analyzed using Turbochrom Data Acquistion system software (PerkinElmer, Oakbrook, IL). Relative response, to correct for injection or detection discrimination, for each component of interest in the sample was determined using known amounts of cholesterol and oxysterol standards in comparison to that of the 5- $\alpha$-cholestane internal standard. Run conditions employed were; helium carrier gas at $40 \mathrm{~cm} / \mathrm{s}$, injector temperature $=300^{\circ} \mathrm{C}, 10 \mu \mathrm{l}$ injections, split ratio $=1$ to 3 , initial column temperature $=250^{\circ} \mathrm{C}$ maintained for $4 \mathrm{~min}$, linear temperature rise to $320^{\circ} \mathrm{C}$ at $5^{\circ} \mathrm{C} / \mathrm{min}$, with final temperature held for $8 \mathrm{~min}$.

Analysis of hepatic lipids. Major hepatic lipid classes were determined in five TgSR +1 - and four control mice that were on the HFHC diet for $25 \mathrm{~d}$. Livers ( 0.5 grams ) were homogenized in a total volume of $5 \mathrm{ml}$ phosphate buffered saline. Aliquots were removed for protein determination (56) and extraction of liver lipids. Homogenized liver $(1.0 \mathrm{ml})$ was extracted with $6 \mathrm{ml}$ ethyl acetate/acetone (2/1:vol/vol) containing $0.01 \%$ butylated hydroxytoluene and a 4-hydroxy-cholesterol (1 mg) internal standard in teflon lined-screw cap 20-ml glass tubes according to the method of Slayback et al. (68). Samples were vigorously mixed for $10 \mathrm{~min}$ and extraction continued overnight. After addition of $2 \mathrm{ml}$ water, and $5 \mathrm{~min}$ low speed centrifugation $(500 \mathrm{rpm})$, the upper phase containing both polar and nonpolar lipids was removed and evaporated to dryness under nitrogen. Residual solvent was removed by lyophilization. Dried lipids were solubilized in $200 \mu \mathrm{l}$ of iso-octane/ tetrahydrofuran (97/3: vol/vol) and $5 \mu \mathrm{l}$ were injected onto a $4.6 \times 100$ $\mathrm{mM}$ silica column equilibrated with iso-octane/tetrahydrofuran (97/3: vol/vol) on a Spectra Physics HPLC by a modification of the method 
of Christie (69). Post column eluant was detected in a evaporative light scattering detector (Varex, model ELSD IIA). Authentic lipid standards were utilized to calibrate the detector response for the various major lipid classes.

Determination of fecal bile acids. Five $\mathrm{TgSR}+/$ - and five control mice were maintained on chow diets in individual metabolic cages for $1 \mathrm{wk}$, followed by a high fat high cholesterol diet for $3 \mathrm{wk}$. Total feces from each mouse were collected at the end of each week and stored at $-20^{\circ} \mathrm{C}$. Total fecal bile acids were determined by the fluorescence method of Beher et al. (70). Briefly, feces were homogenized in three volumes of water. An aliquot of the fecal homogenate (1 gram) was mixed with $7 \mathrm{ml}$ of ethanol and heated to $70^{\circ} \mathrm{C}$ for $30 \mathrm{~min}$. The mixture was then filtered through a pleated filter and washed once with $6 \mathrm{ml}$ of preheated ethanol. A 4-ml aliquot from each sample was dried under nitrogen and then dissolved in $2 \mathrm{ml}$ of $3 \mathrm{M} \mathrm{NaOH}$ and heated at $100^{\circ} \mathrm{C}$ for $2 \mathrm{~h}$. Samples $(10 \mu \mathrm{l}), 2.4 \mathrm{ml}$ of Tris buffer $\mathrm{pH} 9$, and $0.5 \mathrm{ml}$ of reagent ( $2 \mathrm{mg}$ resazurin, $100 \mathrm{mg} \beta-\mathrm{NAD}, 6.4 \mathrm{U}$ of hydroxysteroid oxidoreductase and $37 \mathrm{U}$ of diaphorase in $100 \mathrm{ml}$ of $0.05 \mathrm{M} \mathrm{pH} 7.4$ phosphate buffer containing $19.1 \mathrm{mg}$ sucrose, $0.1 \mu \mathrm{g}$ dithioerythritol, $7.5 \mathrm{mg}$ EDTA, and $50 \mathrm{mg}$ bovine serum albumin) were incubated at room temperature for $1.5 \mathrm{~h}$. Samples were excited at $565 \mathrm{~nm}$ and emission fluorescence determined at $580 \mathrm{~nm}$ in a fluorescence spectrophotometer model LS-3 (Perkin-Elmer, Oakbrook, IL). Standards of cholic acid were used to calibrate the assay.

Cholesterol absorption. Cholesterol absorption was determined in three control and five $\mathrm{TgSR}+/$ - mice by determination of the differential absorption of cholesterol and $\beta$-sitosterol on a HFHC. Briefly, mice individually housed in metabolic cages were maintained ad libitum on a chow diet prior to intragastic bolus administration of ${ }^{3} \mathrm{H}$-cholesterol $(1.5 \mu \mathrm{Ci})$ plus ${ }^{14} \mathrm{C}$ - $\beta$-sitosterol $(0.1 \mu \mathrm{Ci})$ in $100 \mu \mathrm{l}$ sunflower seed oil. Mice were then allowed ad libitum access to the HFHC diet for $4 \mathrm{~d}$. An aliquot of the oral dose and a homogenate of the feces collected over the $4 \mathrm{~d}$ were extracted with ethylene acetate/acetone (2/1:vol/ vol) and processed in a similar fashion as described above for extraction of hepatic lipids. Radioactivity in an aliquot of the lipid phase was determined by liquid scintillation counting. The ratio of ${ }^{3} \mathrm{H}$ to ${ }^{14} \mathrm{C}$ in the extracts were determined and used to estimate percent cholesterol absorption by the following formula:

Percent cholesterol absorption

$=100 \times \frac{\left(\left({ }^{3} \mathrm{H} /{ }^{14} \mathrm{C} \text { in oral dose }\right)-\left({ }^{3} \mathrm{H} /{ }^{14} \mathrm{C} \text { in feces }\right)\right)}{\left({ }^{3} \mathrm{H} /{ }^{14} \mathrm{C} \text { in oral dose }\right)}$

\section{Results}

Creation of SR transgenic mice. To create mice with hepatic expression of the bovine SR type I, a SR minigene containing the mouse transferrin promoter was constructed (Fig. 1). Based on the work of Kozak et al $(50,51), 5 \mathrm{bp}$ of the untranslated region of the bSR cDNA sequence (49) was incorporated into the construct since inclusion of this element should facilitate the correct initiation and highly efficient translation of the SR. In our experiments this concept was not examined rigorously in that we did not construct nor test a minigene lacking these $5 \mathrm{bp}$. The SR minigene was injected into hybrid fertilized eggs obtained from a C57BL/6J female crossed to a FVB male. PCR and Southern blotting indicated three potential transgenic mice were created (data not shown). These mice were breed to C57BL/6J; offspring from these crosses indicated that out of the three potential founders, two were chimerics and one had transgene incorporation into the germline. Southern blot results suggested $\sim 30$ copies of the transgene were present per cell. In some studies, $\mathrm{TgSR}+/$ - were crossed to generate homozygous mice $(\mathrm{TgSR}+/+)$.

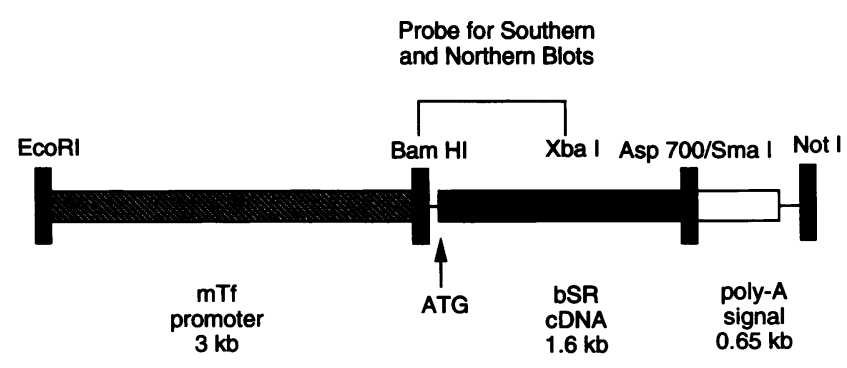

Figure 1. The 5.2-kb construct of the bovine SR type 1 minigene. A full-length bovine SR cDNA (black bar) was truncated in the 3' untranslated region at the single restriction site Asp 700. The $\sim 1.6-\mathrm{kb}$ fragment was then ligated to a $0.65-\mathrm{kb}$ fragment containing the poly $\mathrm{A}$ signal sequence of the human growth hormone gene (open bar) using the SmaI and Asp 700 fusion site. At the 5' end a 3-kb DNA fragment of the mouse transferrin promoter (hatched box) was attached using BamHI. The minigene was inserted into a pGem $11 \mathrm{Zf}(-)$ using EcoRI at the $5^{\prime}$ end and NotI at the $3^{\prime}$ end. The region between the BamHI site at the $3^{\prime}$ end of the mouse transferrin promoter and the first ATG codon of the SR cDNA contained five base pairs $\left(5^{\prime}\right.$-gaagt- $\left.3^{\prime}\right)$ of the untranslated region of the bovine SR allowing the first ATG to be in the optimal context for translation initiation $(50,51)$.

Expression of the bovine $S R$ in transgenic mice. Tissue specific expression of bovine SR mRNA was examined by RTPCR and Northern blot analysis of total RNA isolated from tissues of TgSR+/- and nontransgenic controls (C57BL/6J $\times$ FVB). By RT-PCR a $1 \mathrm{~kb}$ cDNA fragment was amplified in $\mathrm{TgSR}+/-$ but not in control mice (Fig. 2), demonstrating the presence of bovine SR mRNA in the TgSR $+/-$ mouse liver. Bovine SR mRNA was predominantly expressed in liver with a much smaller amount found in kidney. A minute amount of bovine SR expression was also observed in brain (Fig. 2). We estimate, hepatic mRNA levels of the bovine SR to be approximately 20-30-fold higher than the endogenous mouse SR (data not shown).

Detergent solubilized nonreduced liver membrane preparations from the $\mathrm{TgSR}+/-$ mice revealed the presence of monomeric plus possibly monomeric precursors (up to $\sim 80 \mathrm{kD}$ ), dimeric $(\sim 160 \mathrm{kD})$, and trimeric $(\sim 240 \mathrm{kD})$ forms of the bovine SR by Western blotting (Fig. 3).

Hepatic parenchymal and nonparenchymal expression of the bovine scavenger receptor. Histological examination of liver sections following intravenous infusion of fluorescent DiI-acetylated human LDL in control and $\mathrm{TgSR}+/-$ mice indicates the presence of the fluorescence probe in nonparenchymal cells (e.g., sinusoidal cells) (Fig. 4). However, unlike a control mouse, TgSR + / - mouse liver parenchymal cells were fluorescent suggesting these cells expressed the transgene (Fig. 4).

Fractional catabolism of ${ }^{125}$ I acetylated LDL in scavenger receptor transgenic mice. The fractional catabolism of ${ }^{125} \mathrm{I}$ achLDL was determined in five $\mathrm{TgSR}+/$ - and five nontransgenic littermates. Mice were tail vein injected with the probe and 10 $\mu \mathrm{l}$ sinus orbital bleeds were periodically taken up to eight minutes. The $T_{1 / 2}$ for ${ }^{125} \mathrm{I}$ ac-hLDL clearance in the TgSR $+/-$ was 2.5 times faster $(75 \mathrm{~s}$ ) than in control mice (186 s) (Fig. 5). In three $\mathrm{TgSR}+/-$ and three nontransgenic littermates simultaneously injected with both Fucoidan and ${ }^{125} \mathrm{I}$ ac-hLDL, the SR mediated clearance of the probe was blocked (Fig. 5).

Plasma lipids and lipoprotein profiles. Weekly plasma tri- 
A

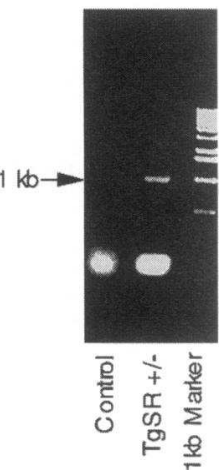

B

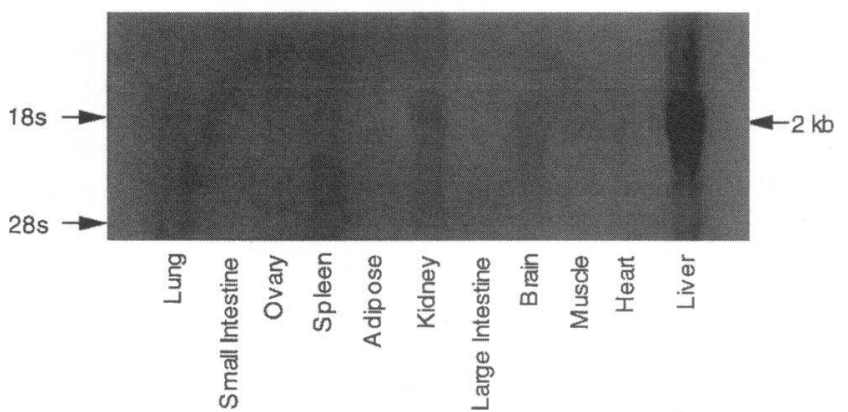

Figure 2. (A) Reverse transcriptase-polymerase chain reaction of hepatic RNA from a control (left lane) and a TgSR $+1-$ mouse (middle lane) shows the presence of a 1-kb amplified region of bovine SR mRNA. Reference DNA size standards are shown (right lane). (B) Northern blot analysis of a bovine SR type I expressing mouse. For each tissue sample $10 \mu \mathrm{g}$ of total RNA was electrophoretically fractionated on a formaldehyde-1\% agarose gel, transferred onto Zetaprobe membranes and then hybridized to a bovine SR type I specific cDNA probe as indicated in Fig. 1. The probe did not hybridize to RNA isolated from control mouse tissues under the same conditions (not shown). The blot was washed and exposed to X-Omat $\mathrm{AR}$ film at $-80^{\circ} \mathrm{C}$ overnight.

glycerides and total cholesterol from control, TgSR $+/-$, and $\mathrm{TgSR}+/+$ mice initially on a chow diet then maintained on the HFHC diet for three weeks are shown in Table I. In all mice and under all dietary conditions plasma triglycerides were similar (Table I). On chow, basal cholesterol levels were similar in control and transgenic mice. When fed the high fat high cholesterol diet, total plasma cholesterol rose in all mice. However, at week three, total plasma cholesterol in the TgSR $+1-$ and $\mathrm{TgSR}+/+$ mice increased to only 59 and $83 \%$, respectively, of that observed in the control mice. High performance gelfiltration chromatographic lipoprotein profile analysis of plasma from these mice (Fig. 6) was used to determine the distribution of cholesterol between lipoproteins (Fig. 7). On the chow diet lipoprotein cholesterol profiles were similar in control and SR transgenic mice; HDL carried the majority of cholesterol under these conditions (Figs. 6 and 7). When fed the HFHC diet, cholesterol predominantly rose in apoB containing lipoproteins relative to HDL in control mice (Figs. 6 and 7). In both $\mathrm{TgSR}+/-$ and $\mathrm{TgSR}+/+$ mice, apoB containing lipoproteins, rose to only half the amount observed in the control mice (Figs. 6 and 7 ). In the TgSR $+/-$ mice, HDL rose more rapidly than

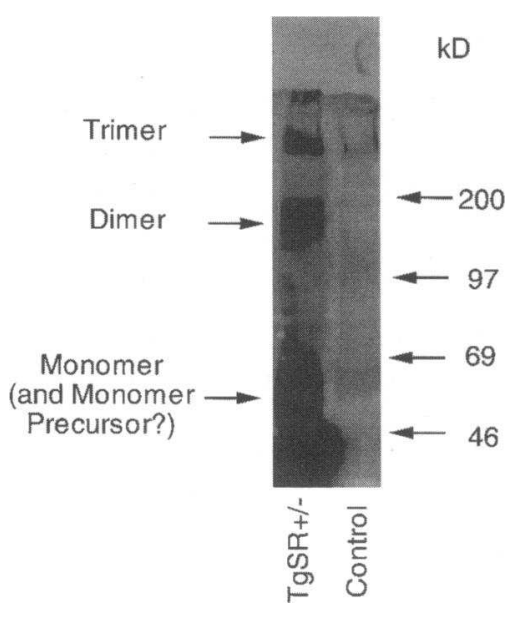

Figure 3. Western blot analysis of a TgSR $+1-$ (left lane) and control (right lane) mouse liver membrane preparation. Nonreduced membrane protein $(22.5 \mu \mathrm{g} /$ lane $)$ was loaded onto $7.5 \%$ SDS polyacrylamide gel and transferred to nitrocellulose membranes and the presence of bovine SR were determined as described in Methods. Monomeric plus possibly monomeric precursors, dimeric, and trimeric forms of the bovine SR are apparent. the controls, however after 3 wk on the HFHC diet HDL cholesterol levels converged (Fig. 7). In contrast, in the TgSR $+/+$ mice fed the HFHC diet, HDL cholesterol continued to rise and the level was significantly greater than control mice levels at three weeks (Figs. 6 and 7). These marked differences in lipoprotein profiles can be appreciated as the ratio of apoB-containing lipoprotein cholesterol to that of HDL cholesterol (Fig. $7)$. Thus, in the $\mathrm{TgSR}+/-$ and $\mathrm{TgSR}+/+$ mice this ratio rose 2.8-fold with the HFHC diet, while this ratio rose to 6.6 -fold in the control mice.

Plasma oxysterols. To determine whether products of cholesterol oxidation would differ due to the overexpression of the SR, $10 \mathrm{TgSR}$, and 8 control mice were maintained on the HFHC diet for 3 wk and plasma from fasted animals were analyzed for oxysterols by gas liquid chromatography. Five of the eight oxysterols monitored were not detectable in the plasma of either transgenic or control mice. Of the detectable plasma oxysterols, the levels were $(\mathrm{mg} / \mathrm{dl} \pm \mathrm{SEM}) ; 4.52 \pm 1.08$ and $2.54 \pm 0.56$ for 3,5-cholestadien-7-one, $2.71 \pm 0.33$ and $2.46 \pm 0.09$ for choles$\tan -5 \alpha, 6 \alpha$-epoxy- $3 \beta$-ol, and $16.37 \pm 2.00$ and $21.26 \pm 0.95$ for 5 cholesten-3 $\beta, 25$-diol in the transgenic and control mice, respectively. By this analysis, plasma cholesterol $(\mathrm{mg} / \mathrm{dl} \pm \mathrm{SEM})$ was $239 \pm 18$ and $246 \pm 23$ in the transgenic and control mice, respectively. Neither oxysterol nor cholesterol levels were statistically different between the control and transgenic mice (unpaired $t$ test).

Cholesterol absorption and food intact studies. Diminished total plasma cholesterol in the transgenic mice could possibly reflect a reduced food intake or an impeded cholesterol absorption. Food intake was therefore recorded over a 3-wk period for five control and five TgSR $+/-$ on the HFHC diet. Average body weight for each group was 22 grams. Weekly food intake was virtually identical between groups; control mice consumed 23.1, 22.9, 24.3 grams/week, while the TgSR $+/-$ mice consumed 21.9, 27.5, 24.7 grams/week, for the first, second and third week, respectively.

Next, cholesterol absorption was determined in three control and five TgSR $+/-$ mice. Animals were oral gavaged with a ${ }^{3} \mathrm{H}$-cholesterol $/{ }^{14} \mathrm{C}$ - $\beta$-sitosterol in sunflower oil, placed on the HFHC diet and feces were collected for four days. The ${ }^{3} \mathrm{H} /{ }^{14} \mathrm{C}$ ratio in the oral dose and in the neutral lipid fraction extracted 


\section{Control 250x}

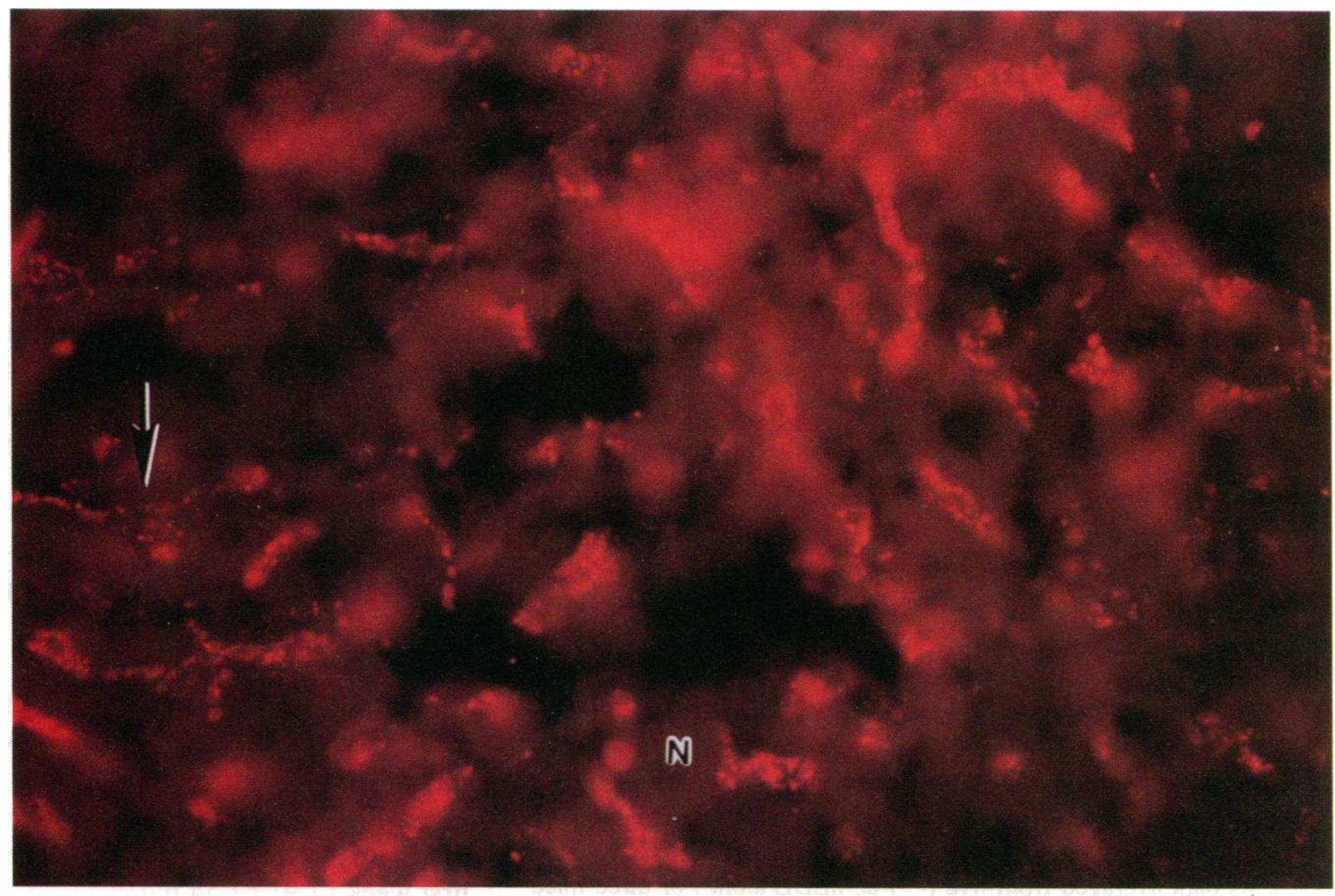

\section{Transgenic 1000x}

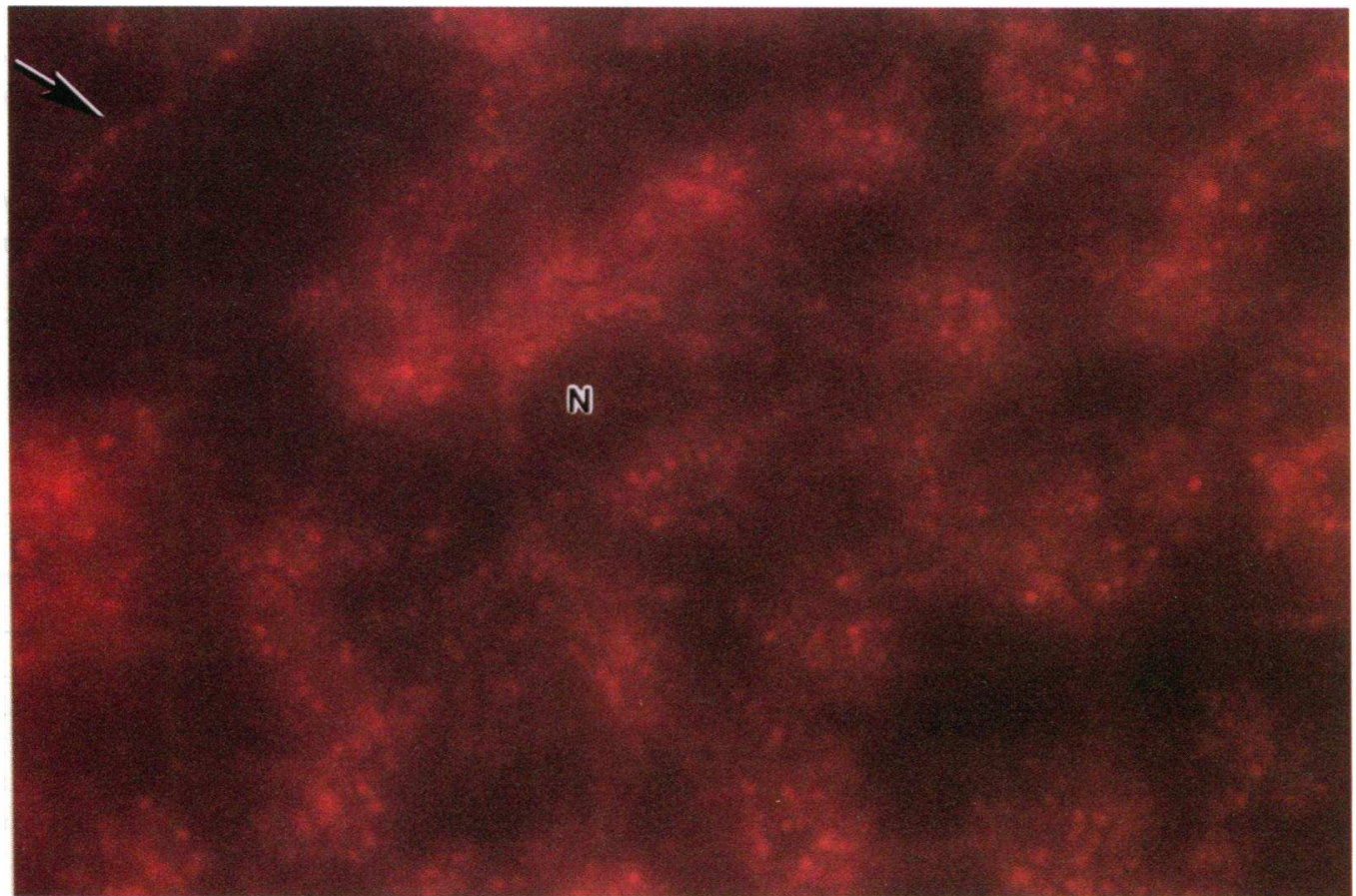

Figure 4. Hepatic fluorescent histochemistry after DiI-acetylated human LDL infusion in control and TgSR $+/-$ mice. Mice were intravenously infused with Dil-acetylated human LDL and sacrificed after $10 \mathrm{~min}$. Liver pieces were embedded in O.C.T., 3-5 mM slices prepared, and viewed by fluorescent microscopy using a rhodamine filter set. The upper panel shows a control mouse hepatic section demonstrating nonparenchymal cell DiI uptake evidenced by fluorescence being confined to elongated cells surrounding sinusoids. The lower panel shows a section from a TgSR $+/-$ mouse. In addition DiI uptake by nonparenchymal cells, extensive dye uptake occurred in polyhedral shaped parenchymal cells (donut-shaped cells) as evidenced by the perinuclear staining. Sinusoidal cells, arrows; $N$, parenchymal cell nucleus. 


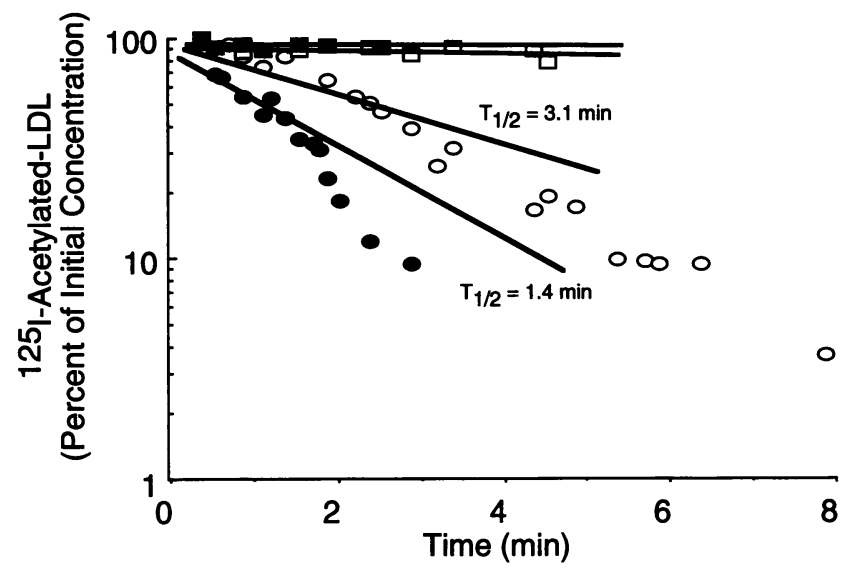

Figure 5. Clearance of ${ }^{125} \mathrm{I}$-acetylated-hLDL in control and $\mathrm{TgSR}+/-$ mice. Five TgSR $+/-(\bullet)$ and five control $(O)$ mice were tail vein injected with ${ }^{125} \mathrm{I}$-ac-hLDL. Blood samples were collected periodically up to $8 \mathrm{~min}$ to determine plasma radioactivity clearance. To control for non-scavenger receptor mediated ${ }^{125} \mathrm{I}$-ac-hLDL clearance, three $\mathrm{TgSR}+1-(\square)$ and three control $(\square)$ mice were coinjected with $0.1 \mathrm{ml}$ of ${ }^{125} \mathrm{I}$-ac-hLDL preparation plus $0.1 \mathrm{ml}$ Fucoidan. Radioactivity data are expressed as percent of the first 20 -s time point. Each data point represents data averaged from five $\left({ }^{125} \mathrm{I}-\mathrm{ac}-\mathrm{hLDL}\right.$ alone $)$ or three mice ( ${ }^{125} \mathrm{I}-\mathrm{ac}-\mathrm{hLDL}$ plus Fucoidan).

from the feces was utilized to estimate the amount of cholesterol absorbed. The percent cholesterol absorption was similar in control $(56.8 \pm 3.4)$ and $\mathrm{TgSR}+1-(56.6 \pm 4.4)$ mice.

Overall, these studies suggest the diminished levels of plasma cholesterol observed in the SR transgenic mice were not the result of reduced food intake or cholesterol absorption.

Hepatic lipids. Gross visual examination of control and TgSR + / - livers from mice maintained on chow diets showed no evidence of fatty accumulations. Livers of control mice fed the HFHC diet showed considerable fat accumulation. In contrast, livers from $\mathrm{TgSR}+/-$ mice fed the HFHC diet appeared normal (not shown) or only slightly discolored (shown) (Fig. 8). To determine whether hepatic lipids would accumulate in the SR transgenic mice, lipid analysis was performed on the four control and five TgSR $+/-$ mice after three weeks on the high fat high cholesterol diet (i.e., from animals studied in Table I, Figs. 6 and 7). In the TgSR $+/-$ mice, hepatic cholesteryl esters, triglycerides and non-esterified cholesterol did not accumulate, but were instead significantly reduced by 59,61 , and 36 percent, respectively (Fig. 8). Hepatic phosphatidylethanolamine and phosphatidylcholine levels were similar (Fig. 8).

Fecal bile acids. To determine whether there would be an increase flux of bile acids in the SR transgenic mice, total fecal bile acids were determined weekly in five control and five TgSR $+1-$ mice fed chow one week, and the HFHC diet for 3 wk. On chow, fecal bile acids were similar in control $(1.51 \pm 0.20 \mathrm{mg} / \mathrm{wk})$ and $\mathrm{TgSR}+/-(1.37 \pm 0.04 \mathrm{mg} / \mathrm{wk})$ mice. On the HFHC diet, fecal bile acids markedly increased 5.4fold by one week $(8.19 \pm 0.95 \mathrm{mg} / \mathrm{wk})$ and remained constant throughout the study (week two, $8.06 \pm 1.65 \mathrm{mg} / \mathrm{wk}$; week three, $8.49 \pm 0.36 \mathrm{mg} / \mathrm{wk})$. Similarly, the fecal bile acids in TgSR $+1-$ mice fed the HFHC diet increased 5.8-fold in the first week $(7.91 \pm 1.54 \mathrm{mg} / \mathrm{wk})$. In contrast, however, fecal bile acids in the subsequent two weeks progressively increased becoming significantly elevated by the third week (week two, $9.23 \pm 1.17 \mathrm{mg} / \mathrm{wk}$; week three, $10.83 \pm 0.33 \mathrm{mg} / \mathrm{wk}$ ) (Fig. 9).

Hepatic $7 \alpha$-hydroxylase mRNA levels. To determine if messenger RNA levels for $7 \alpha$-hydroxylase (the rate limiting enzyme for hepatic bile acid synthesis) were elevated to a greater extent in the TgSR $+/-$ mice, total hepatic RNA was extracted from two control and two $\mathrm{TgSR}+1-$ mice maintained on the HFHC diet for three weeks. Northern blot analysis demonstrates $7 \alpha$-hydroxylase mRNA levels relative to mouse actin mRNA were elevated twofold in the TgSR $+/-$ compared with the control mice (Fig. 10).

Table I. Plasma Cholesterol and Triglyceride Values

\begin{tabular}{|c|c|c|c|c|c|c|c|}
\hline \multirow[b]{2}{*}{ Diet } & \multirow[b]{2}{*}{ Genotype } & \multirow[b]{2}{*}{$\mathbf{N}$} & \multicolumn{3}{|c|}{ Cholesterol (mg/dl) } & \multirow{2}{*}{$\begin{array}{c}\text { Cholesterol ratio } \\
\text { VLDL + IDL + LDL/HDL }\end{array}$} & \multirow{2}{*}{$\begin{array}{c}\text { Triglyceride } \\
\text { (mg/dl) }\end{array}$} \\
\hline & & & Total & VLDL + IDL + LDL & HDL & & \\
\hline \multirow[t]{3}{*}{ Chow diet } & Control & 5 & $60 \pm 7$ & $15 \pm 3$ & $45 \pm 4$ & $0.326 \pm 0.031$ & $49 \pm 3$ \\
\hline & TgSR+1- & 5 & $59 \pm 6$ & $14 \pm 2$ & $45 \pm 5$ & $0.318 \pm 0.021$ & $51 \pm 10$ \\
\hline & TgSR+/+ & 3 & $78 \pm 7$ & $21 \pm 2$ & $56 \pm 5$ & $0.383 \pm 0.019$ & $56 \pm 4$ \\
\hline \multirow[t]{3}{*}{ 1-wk high fat high cholesterol diet } & Control & 5 & $203 \pm 37$ & $132 \pm 28$ & $71 \pm 10$ & $1.800 \pm 0.204$ & $52 \pm 6$ \\
\hline & $\operatorname{TgSR}+/-$ & 5 & $174 \pm 17$ & $70 \pm 10^{\ddagger}$ & $105 \pm 8^{\ddagger}$ & $0.656 \pm 0.041^{\|}$ & $60 \pm 7$ \\
\hline & TgSR $+/+$ & 4 & $180 \pm 15$ & $77 \pm 13^{*}$ & $104 \pm 7 *$ & $0.752 \pm 0.133^{\prime \prime}$ & $55 \pm 6$ \\
\hline \multirow[t]{3}{*}{ 2-wk high fat high cholesterol diet } & Control & 5 & $242 \pm 26$ & $155 \pm 19$ & $88 \pm 8$ & $1.768 \pm 0.136$ & $39 \pm 3$ \\
\hline & $\operatorname{TgSR}+1-$ & 5 & $190 \pm 15$ & $85 \pm 8^{\ddagger}$ & $105 \pm 10^{\|}$ & $0.828 \pm 0.098^{\|}$ & $53 \pm 19$ \\
\hline & $\mathrm{TgSR}+1+$ & 4 & $256 \pm 21^{9}$ & $99 \pm 8^{*}$ & $157 \pm 16^{\ddagger \ddagger}$ & $0.650 \pm 0.055^{\|}$ & $52 \pm 2$ \\
\hline \multirow[t]{3}{*}{ 3-wk high fat high cholesterol diet } & Control & 4 & $323 \pm 35$ & $226 \pm 29$ & $96 \pm 7$ & $2.340 \pm 0.204$ & $38 \pm 2$ \\
\hline & $\mathrm{TgSR}+1-$ & 5 & $192 \pm 17^{\|}$ & $93 \pm 14^{\| \prime}$ & $100 \pm 11$ & $1.004 \pm 0.240^{\prime \prime}$ & $27 \pm 1$ \\
\hline & $\mathrm{TgSR}+/+$ & 4 & $270 \pm 13^{\pi}$ & $132 \pm 15^{\S}$ & $138 \pm 11^{\ddagger * *}$ & $0.998 \pm 0.181^{\|}$ & $86 \pm 27^{\ddagger \ddagger \ddagger}$ \\
\hline
\end{tabular}

Plasma lipids and lipoprotein levels in control, heterozygous transgenic bovine scavenger receptor ( $\operatorname{TgSR}+/-$ ), and homozygous transgenic bovine scavenger receptor $(\mathrm{TgSR}+/+$ ) mice. Blood samples were obtained following an eight hour fast from mice on the chow diet; and after one, two and three weeks on the high fat high cholesterol diet. Data represent mean \pm SEM. $P$ values derived from ANOVA, Fisher's PSLD post-hoc analysis. Compared to respective control $* P<0.05,{ }^{\ddagger} P<0.01,{ }^{8} P<0.001$, " $P<0.0001$. TGSR $+/+$ compared to respective TgSR+/- $1 P<0.05$, ** $P<0.01$, ${ }^{\ddagger \ddagger} P<0.001$. 


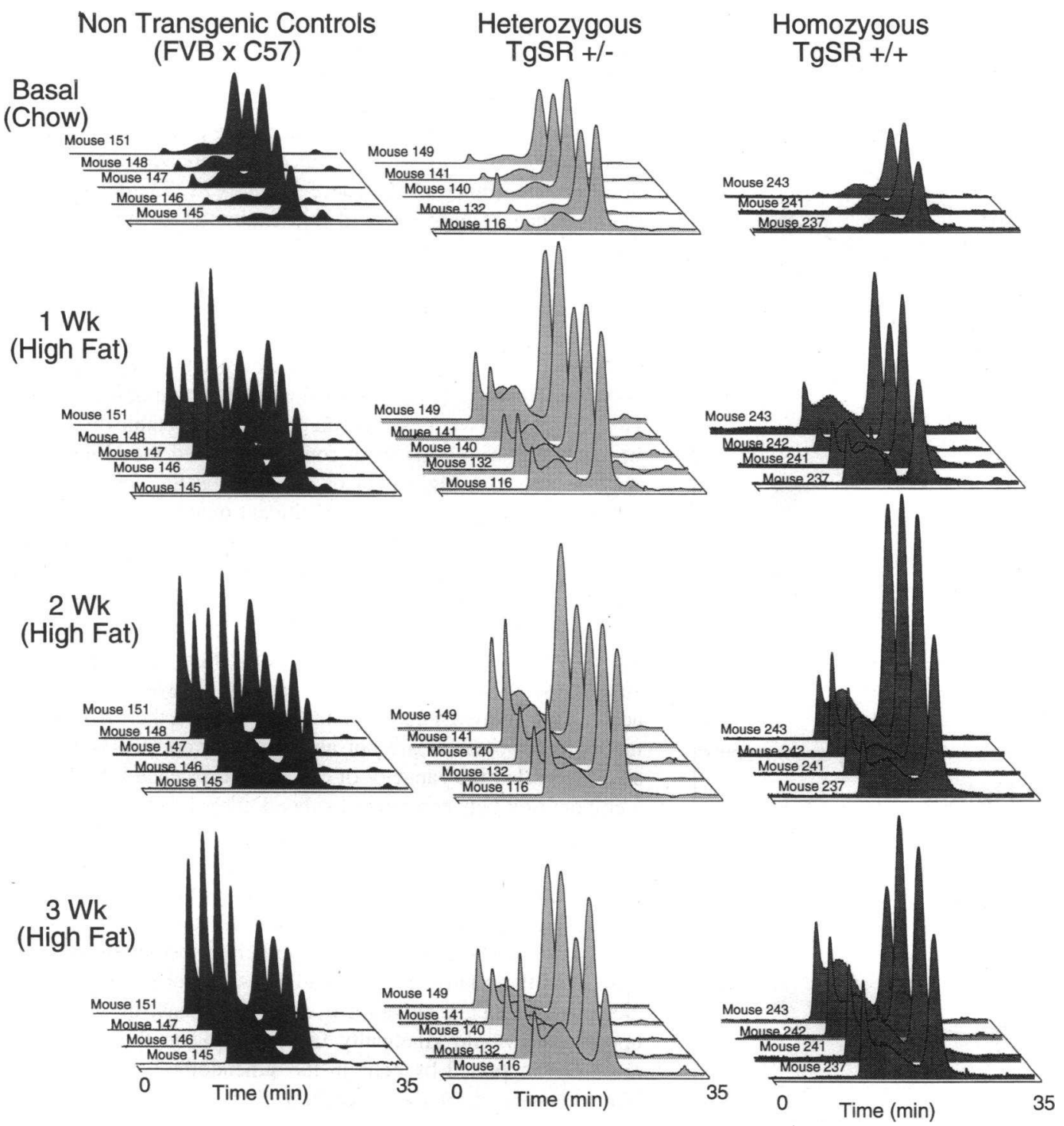

Figure 6. Lipoprotein cholesterol analysis of plasma from non transgenic control (FVB $\times$ C57BL/6J), TgSR $+/-$, and TgSR $+/+$ mice maintained on chow or fed the HFHC diet for up to three weeks. High performance gel-filtration chromatographic lipoprotein profile analysis of $10 \mu \mathrm{l}$ plasma from these mice was determined weekly as described in Methods. A blood sample from TgSR $+1+$ mouse No. 242 on chow was not obtained, and control mouse No. 148 died from anesthesia overdose at 2 wk. Although not shown on the figure, the peak height $(y$-axis) $=$ OD 490 is the same scale for each of the 12 groups shown.

\section{Discussion}

Using genetically engineered mice created to overexpress hepatic SR, the current studies have attempted to answer whether these site specific receptors play a functional role in removal of potentially atherogenic lipoproteins. To promote murine liver specific expression of the bovine SR type I, we utilized the mouse transferrin promoter in the minigene construct. When the TgSR mice were fed an atherogenic diet we observed neither a difference in food intake nor in absorption of cholesterol. However, their plasma lipoprotein profiles showed reduced accumulation of apoB containing lipoprotein cholesterol. This effect was quite dramatic. TgSR $+/-$ mice showed almost a twofold reduction in the rise of apoB containing lipoproteins after a week on the HFHC diet as compared to the non-transgenic mice. This differential response was consistent throughout the 3-wk feeding period. This was in sharp contrast to the normal chow feeding period, in which the nontransgenic and transgenic mice maintained virtually equivalent lipoprotein profiles. Furthermore, when the TgSR $+/-$ mice were on the HFHC diet, a compensatory rise in hepatic cholesterol was not observed; in fact, both hepatic cholesterol and cholesteryl esters were reduced in the transgenic mice. These data suggested an enhanced secretion of biliary cholesterol as bile acids. Indeed, both hepatic $7 \alpha$-hydroxylase mRNA levels and total fecal bile acids were elevated in the transgenic mice. Overall, these studies suggest that the overexpression of the hepatic SR enhanced the flux of cholesterol secretion.

Based on our Northern blotting experiments in tissues from TgSR mice, SR mRNA expression was indeed confined pre- 


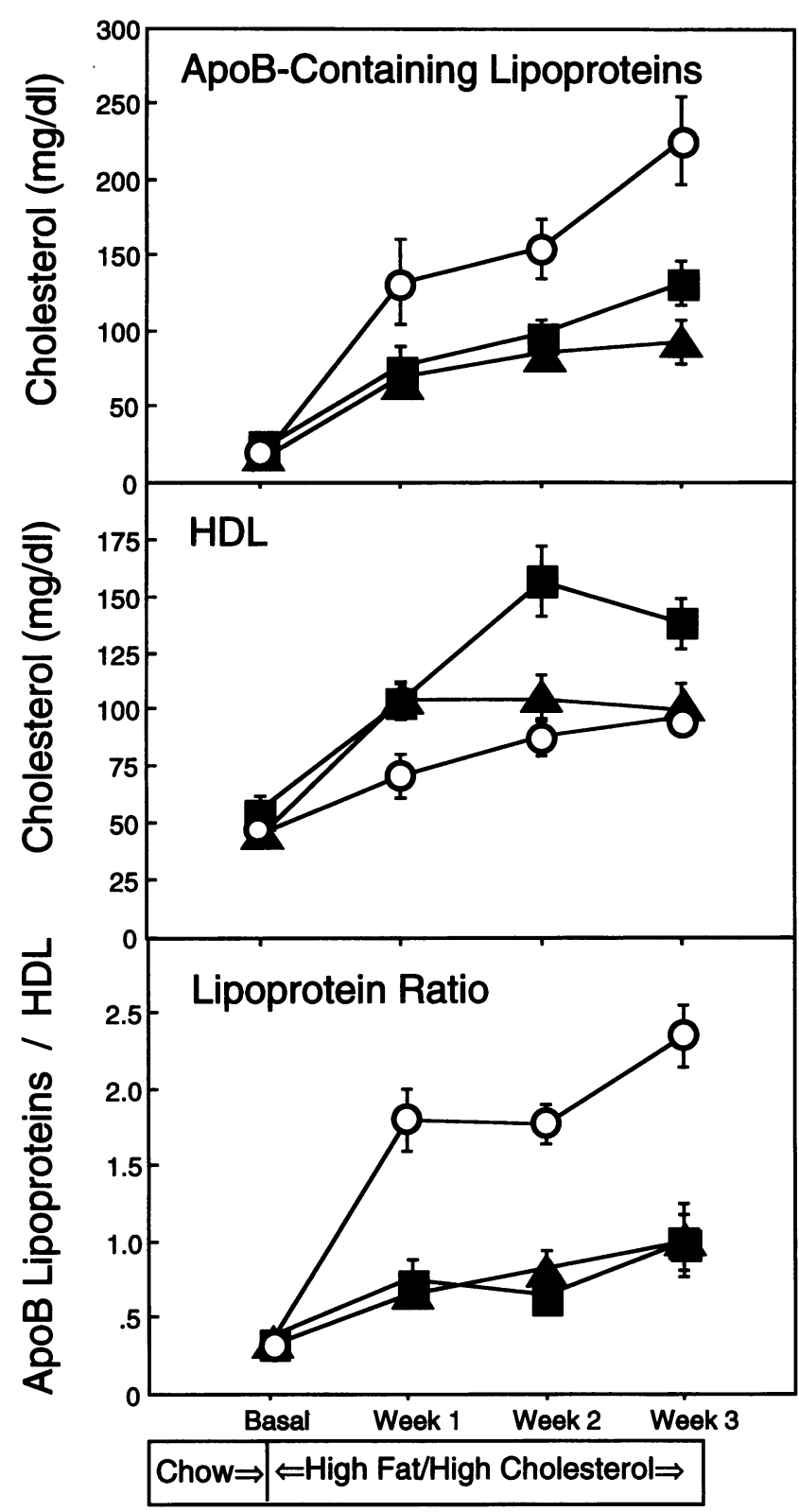

Figure 7. Plasma cholesterol in apolipoprotein B containing lipoproteins (upper panel), HDL (middle panel), and the apolipoprotein B containing lipoprotein to HDL cholesterol ratio (lower panel) in nontransgenic control (O, $n=4$ or 5$), \mathrm{TgSR}+/-(\Lambda, n=5)$, and TgSR $+I+(\square, n=3$ or 4$)$ mice maintained on chow or fed the HFHC diet for up to three weeks. Total plasma cholesterol (Table I) and lipoprotein profiles from data shown in Fig. 6 were used for the determinations. Data points represent the mean \pm SEM.

dominantly to the liver. Hepatic fluorescent microscopy of the $\mathrm{TgSR}+/-$ mice injected with Di-I acetylated-LDL demonstrated SR activity in the sinusoidal endothelial cells, which normally express SR $(12,38-45)$ and also in hepatocytes in which SR are normally barely detectable (41).

As has been suggested by the early studies from the laboratory of Brown and Goldstein (6), SR have been hypothesized to play a protective role in atherogenesis by removing modified lipoproteins. Indeed, apoB containing lipoproteins from rabbits fed high cholesterol diets are more susceptible to $\mathrm{Cu}^{2+}$ induced modification than LDL isolated from control rabbits in vitro (71). Although direct evidence for the existence of circulating modified lipoproteins is sparse, studies of Palinski et al (72, 73) have indirectly suggested the presence of in vivo oxidative modification of LDL in LDL-receptor deficient rabbits and apoE-deficient mice $(74)$. These studies $(72,73)$ demonstrate the presence of high titers of autoantibodies to malondialdehyde-lysine, an epitope that presents on "modified" lipoproteins. The studies of Hodis et al (65-67) have shown the presence of increased levels of plasma oxysterols in cholesterolfed rabbits and cynomolgus monkeys. However, in the current studies we were unable to detect a difference in oxysterol levels between the control and SR transgenic mice maintained on the HFHC diet for $3 \mathrm{wk}$. Possibly, the lack of a detectable difference in oxysterols in plasma from control mice fed the HFHC diet may be due to a high level of endogenous SR activity. This finding does not exclude that significant quantities of modified apoB containing lipoproteins may have been formed in mice fed the HFHC diet and that overexpression of the SR is responsible for reduced amounts of apoB containing lipoproteins. This hypothesized premise suggests that the SR expressed in vivo are exquisitely sensitive to slight modifications of lipoproteins, since these modified lipoproteins can not always be shown to accumulate in hypercholestolemic plasmas. Furthermore, since modified lipoproteins are not always observed in plasma it is also likely that the capacity of SR are not exceeded. However, a competition between arterial subendothelial SR with those of liver likely exists. Thus, under conditions where hepatic SR expression is high, modified lipoproteins would be less likely to bind SR present in the aortic subendothelium. However, in certain pathophysiological or procedural induced conditions (e.g., angioplasty), the arterial endothelium becomes compromised and the relative number and assess to subendothelial SR increases. If such a situation occurs in humans, the modified lipoproteins would kinetically favor binding to the scavenger receptors expressed by cells in the subendothelium and could lead to enhanced arterial lipid deposition.

With respect to reduction of apoB containing lipoproteins we did not observe a gene dosage effect between the TgSR $+/-$ and the TgSR $+/+$ mice. Possibly, sufficient SR are produced in the heterozygous animals to efficiently remove all modified lipoproteins that form in these mice. The elevated rise in HDL was unexpected. The observation that HDL rose to a greater extent in the $\mathrm{TgSR}+/+$ mice, or earlier in the $\mathrm{TgSR}+/-$ and $\mathrm{TgSR}+/+$ mice suggested alterations in HDL metabolism. The explanation for this finding is not entirely clear and is cause for some speculation. Possibly, the catabolism of HDL is diminished in these mice. This may occur due to an increase removal of apoE with apoB containing particles, possibly reducing the apoE pool necessary for whole HDL particle clearance (75). Alternatively, HDL production may be enhanced in these mice. This may occur due to increased expression of the scavenger receptor. Possibly, elevated amounts of modified VLDL remnants are marginated within the liver due to the increased amount of SR. The triglyceride and phospholipid of the trapped remnants, as well as circulating VLDL remnants and HDL, are hepatic lipase substrates (76). Unlike other species, in mice, although liver derived, hepatic lipase is not anchored to liver membrane glycosaminoglycan but freely circulates (77). Therefore increased levels of this enzyme may be sequestered near 

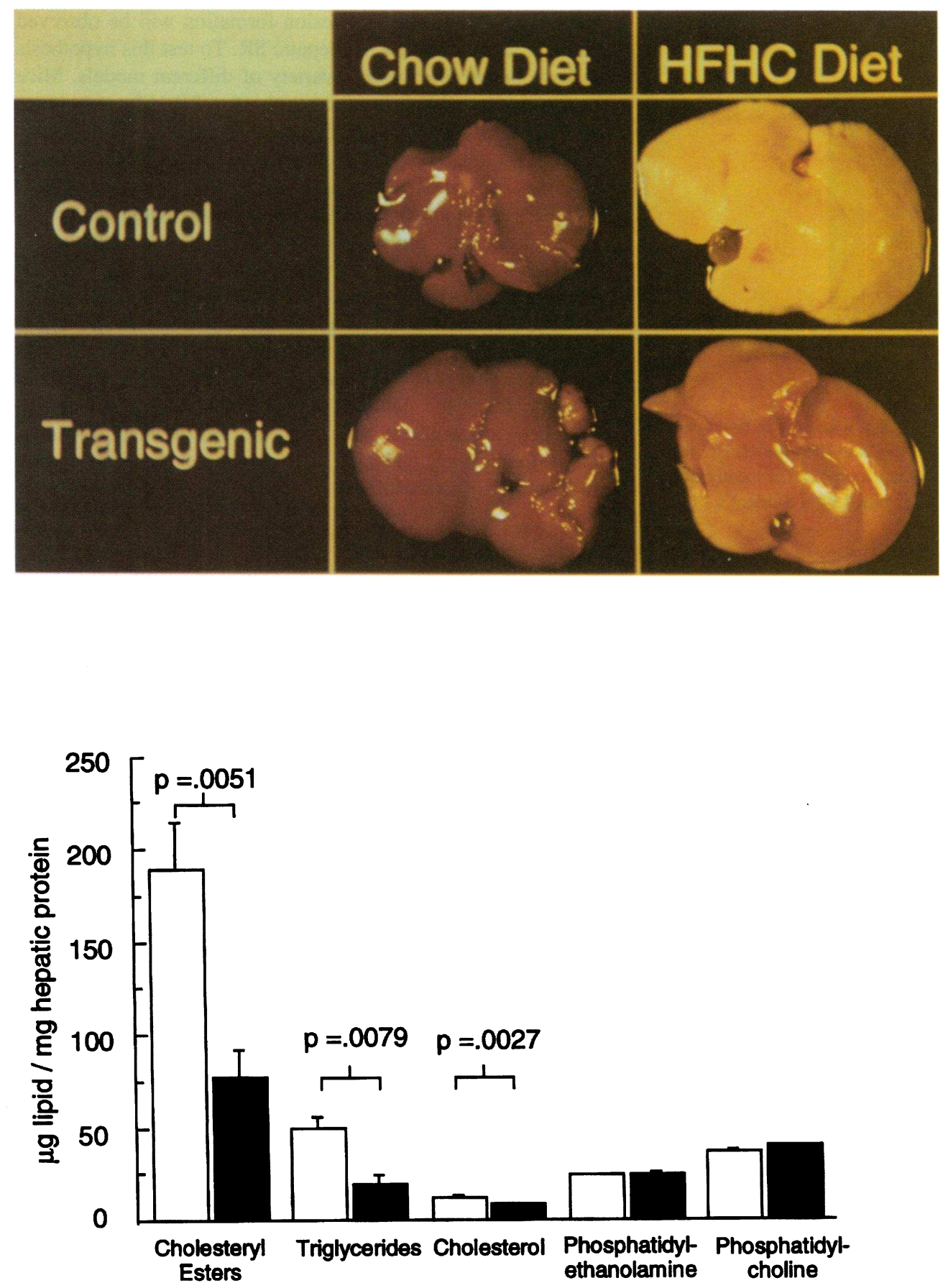

Figure 8. Hepatic lipid analyis in $\mathrm{TgSR}+1-$ mice. In the upper panel, typical livers from control and $\mathrm{TgSR}+/$ - mice maintained on chow diets showed no evidence of the fatty accumulation. Livers from control mice fed the HFHC diet were always white indicative of a fatty liver, while livers from TgSR $+/-$ mice fed the HFHC diet appeared only slightly discolored. The lower panel shows hepatic lipid analysis from the four control (ㅁ) and five TgSR+ $/-$ (घ) mice after three weeks on the high fat high cholesterol diet (i.e., from animals studied in Table I, Figs. 6 and 7). Data represent the mean $\pm S E M$. Significance difference in mean was determined by a Student's $t$ test for unpaired data.

its site of synthesis due to the increased presence of bound modified VLDL remnant substrate to the SR receptors. Enhanced lipolysis of these modified "remnants" by hepatic lipase would lead to generation of redundant surface phospholipid that could potentially elevate production of the HDL pool (78-81). Since mice lack cholesteryl ester transfer protein (82), HDL triglyceride cannot be efficiently derived from VLDL and VLDL remnants by exchange with HDL cholesteryl esters (83), therefore expansion of the particles' nonpolar core will be largely due to cholesteryl ester accumulation. Since HDL phospholipid surface are also substrate for hepatic lipase, and if this enzyme is largely sequestered in the liver due to the increase presence of bound modified particles, a secondary effect would be reduced levels of circulating hepatic lipase. Therefore, an altered HDL catabolism might develop. Possibly, the phospholipid surface of these particles might not be subject to extensive lipolysis, which could allow these HDL to be better substrates for lecthin:cholesterol acyl transferase resulting in accumulation of core cholesteryl esters.

Although our studies do not directly demonstrate the overexpression of hepatic SR is protective for atherosclerosis, the 2.5fold enhanced clearance rate for ac-hLDL in the transgenic mice suggests a hepatic directed clearance. Based on the reduction in the level of apoB containing lipoproteins in the circulation, 


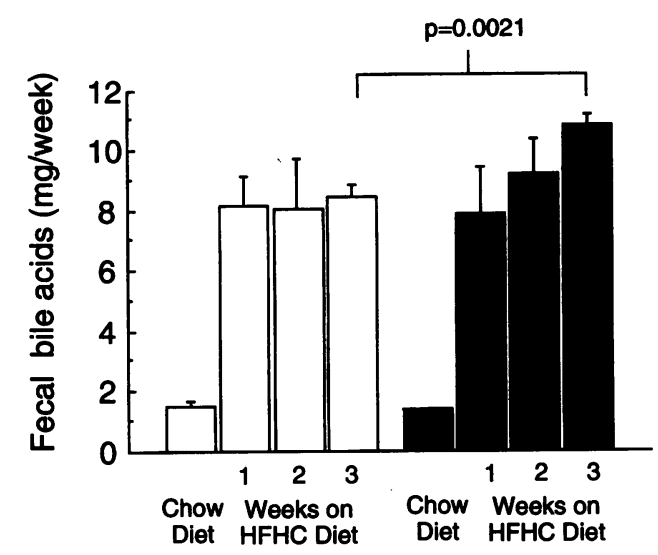

Figure 9. Total fecal bile acids were determined weekly in five control ( $\square$ ) and five TgSR $+/-(\square)$ mice fed chow, and then the HFHC diet for three weeks as described in Methods. Data represent the mean \pm SEM. Significance difference in mean was determined by a Student's $t$ test for unpaired data.

Mouse $7 \alpha$-hydroxylase

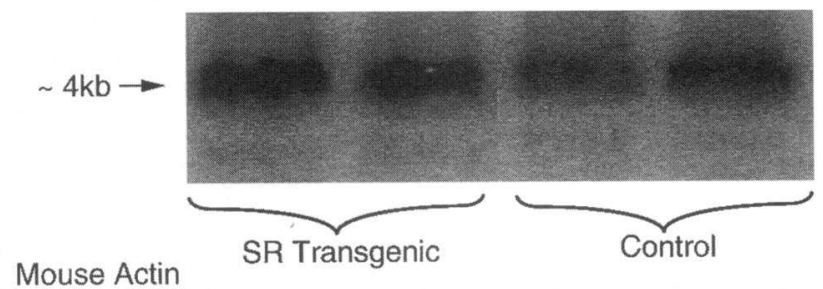

Mouse Actin

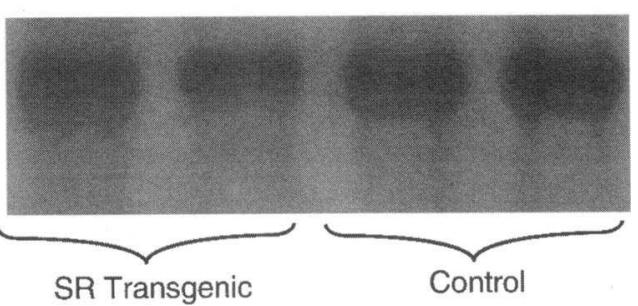

Mouse $7 \alpha$-hydroxylase to Mouse Actin Ratio

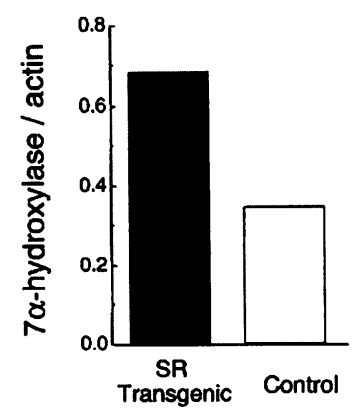

Figure 10. Hepatic 7- $\alpha$ hydroxylase mRNA levels. Two control and two TgSR $+/-$ mice were fed the HFHC diet for three weeks. Hepatic total RNA ( $10 \mu \mathrm{g} / \mathrm{lane})$ were run on duplicate gels, blotted and probed for mouse $7 \alpha$-hydroxylase or mouse actin as described in Methods. The $7 \alpha$-hydroxylase to actin ratio was elevated twofold in the SR transgenic mice. we postulate that decreased lesion formation will be observed in mice that overexpress the hepatic SR. To test this hypothesis we have begun to explore a variety of different models. Mice have been created that overexpress bovine $S R$ in bone marrow and peritoneal macrophages. Studies to determine if this condition exasperates atherosclerosis are ongoing. Additional studies of crosses between TgSR to apoE deficient mice are also ongoing to determine whether hepatic SR overexpression can rescue the apoE deficient mice from production of autoantibodies to modified lipoproteins (73), overproduction of vascular cell adhesion molecule-1 (84), and atherosclerosis development (74, 85-87). Similarly, we are also assessing whether the TgSR mice can rescue LDL receptor deficient mice from atherosclerosis development $(88,89)$. The outcome of these rescue studies will help focus the potential use of somatic gene therapy to direct hepatic specific expression of the SR. However, the technology for delivery and long term somatic expression of gene products is still in its infancy.

\section{Acknowledgments}

The authors gratefully acknowledge the generous gifts of the transferrin promoter from Stanley A. McKnight (University of Seattle, WA), antibodies to the scavenger receptor cytoplasmic domain from Robert $\mathrm{E}$. Pitas (Gladstone Institute, San Francisco, CA) and radiolabeled $\beta$-sitosterol from Lawrence L. Rudel (Bowman Gray School of Medicine). The authors also would like to thank Gerri Hanten (Baylor College of Medicine) for technical assistance in microinjection, and to Blake Barnett, Arnold Essenburg, Reynold Homan, Cara Stewart, and Thomas M. Stickney, (all of Parke-Davis Pharmaceutical Research) for assistance with various aspects of lipid and lipoprotein analysis and characterization of the mice, and to Michael Pape (also of Parke-Davis), for providing rat specific primers for $7-\alpha$ hydroxylase used to isolate a mouse cDNA fragment.

This work was supported in part by a grant from the National Institutes of Health (HL-27341) for a Specialized Center of Research in Arteriosclerosis at Baylor College of Medicine.

\section{References}

1. Brown, M. S., J. L. Goldstein, M. Krieger, Y. K. Ho, and R. G. W. Anderson. 1979. Reversible accumulation of cholesteryl esters in macrophages incubated with acetylated lipoproteins. J. Cell Biol. 82:597-613.

2. Goldstein, J. L., Y. K. Ho, S. K. Basu, and M. S. Brown. 1979. Binding site on macrophages that mediates uptake and degradation of acetylated low density lipoprotein, producing massive cholesterol deposition. Proc. Natl. Acad. Sci. USA. 76:333-337.

3. Brown, M. S., and J. L. Goldstein. 1983. Lipoprotein metabolism in the macrophage: Implications for cholesterol deposition in atherosclerosis. Ann. Review Biochem. 52:223-261.

4. Steinberg, D., S. Parthasarathy, T. E. Carew, J. C. Khoo, and J. L. Witztum. 1989. Beyond Cholesterol. Modifications of low-density lipoprotein that increase its atherogenicity. N. Engl. J. Med. 320:915-924.

5. Carew, T. E. 1989. Role of biologically modified low-density lipoprotein in atherosclerosis. Am. J. Cardiol. 64:18G-22G.

6. Brown, M. S., and J. L. Goldstein. 1990. Scavenging for receptors. Nature. 343:508-509

7. Kurihara, Y., A., Matsumoto, H. Itakura, and T. Kodama. 1991. Macrophage scavenger receptors. Curr. Opin. Lipidology. 2:295-300.

8. Krieger, M. 1992. Molecular flypaper and atherosclerosis: structure of the macrophage scavenger receptor. TIBS. 17:141-146.

9. Fogelman, A. M., I. Shechter, J. Seager, M. Hokom, J. S. Child, and P. A. Edwards. 1980. Malondialdehyde alteration of low density lipoproteins leads to cholesteryl ester accumulation in human monocyte macrophages. Proc. Natl. Acad. Sci. USA. 77:2214-2218.

10. Haberland, M.E., and A. M. Fogelman. 1985. Scavenger receptor-mediated recognition of maleyl bovine plasma albumin and demaleyated protein in human monocyte macrophages. Proc. Natl. Acad. Sci. USA. 82:2693-2697. 
11. Horiuchi, S., M. Murakami, K. Takata, and Y. Morino. 1986. Scavenger receptor for aldehyde-modified proteins. J. Biol. Chem. 261:4962-4966.

12. Dresel, H. A., E. Friedrich, D. P. Via, H. Sinn, R. Ziegler, and G. Schettler 1987. Binding of acetylated low density lipoprotein and maleylated bovine serum albumin to the rat liver: one or two receptors? EMBO (Eur. Mol. Biol. Organ.) J. 6:319-326.

13. Quinn, M. T., S. Parthasarathy, L. G. Fong, and D. Steinberg. 1987. Oxidatively modified low density lipoproteins: A potential role in recruitment and retention of monocyte/macrophages during atherogenesis. Proc. Natl. Acad. Sci. USA. 84:2995-2998.

14. Takata, K., S. Horiuchi, N. Araki, M. Shiga, M. Saitoh, and Y. Morino 1988. Endocytic uptake of nonenzymatically glycosylated proteins is mediated by a scavenger receptor for aldehyde-modified proteins. J. Biol. Chem. 263:1481914825.

15. Wright, T. L., F. J. Roll, A. L. Jones, and R. A. Weisiger. 1988. Uptake and metabolism of polymerized albumin by rat liver. Role of the scavenger receptor. Gastroenterology. 94:442-452.

16. Takata, K., S. Horiuchi, and Y. Morino. 1989. Scavenger receptor-mediated recognition of maleylated albumin and its relation to subsequent endocytic degradation. Biochim. Biophys. Acta. 984:273-280.

17. Eskild, W., G. M. Kindberg, B. Smedsrød, R. Blomhoff, K. R. Norum, and T. Berg. 1989. Intracellular transport of formaldehyde-treated serum albumin in liver endothelial cells after uptake via scavenger receptors. Biochem. J. 258:511-520.

18. Steinbrecher, U. P., M. Lougheed, W.-C. Kwan, and M. Dirks. 1989. Recognition of oxidized low density lipoprotein by the scavenger receptor of macrophages results from derivatization of apolipoprotein B by products of fatty acid peroxidation. J. Biol. Chem. 264:15216-15223.

19. Hampton, R. Y., D. T. Golenbock, M. Penman, M. Krieger, and C. R. H. Raetz. 1991. Recognition and plasma clearance of endotoxin by scavenger receptors. Nature (Lond.). 352:342-344.

20. Stehle, G., E. A. Friedrich, H. Sinn, A. Wunder, J. Harenberg, C. E. Dempfle, W. Maler-Borst, and D. L. Heene. 1992. Hepatic uptake of a modified low molecular weight heparin in rats. J. Clin. Invest. 90:2110-2116.

21. Tokuda, H., S. Masuda, Y. Takakura, H. Sezaki, and M. Hashida. 1993. Specific uptake of succinylated proteins via a scavenger receptor-mediated mechanism in cultured brain microvessel endothelial cells. Biochem. Biophys. Res. Commun. 196:18-24.

22. de Vries, H. E., J. Kuiper, A. G. de Boer, T. J. C. van Berkel, and D. D. Breimer. 1993. Characterization of the scavenger receptor on bovine cerebral endothelial cells in vitro. J. Neurochem. 61:1813-1821.

23. Pearson, A. M., A. Rich, and M. Krieger. 1993. Polynucleotide binding to macrophage scavenger receptor depends on the formation of base-quartetstabilized four-stranded helices. J. Biol. Chem. 268:3546-3554.

24. Zhang, H., Y. Yang, and U. P. Steinbrecher. 1993. Structural requirements for the binding of modified proteins to the scavenger receptor of macrophages. J. Biol. Chem. 268:5535-5542.

25. Dunne, D. W., D. Resnick, J. Greenberg, M. Krieger, and K. A. Joiner. 1994. The type I macrophage scavenger receptor binds to gram-positive bacteria and recognizes lipoteichoic acid. Proc. Natl. Acad. Sci. USA. 91:1863-1867.

26. Freeman, M. W. 1994. Macrophage scavenger receptors. Curr. Opin Lipidology. 5:143-148.

27. Bickel, P. E., and M. W. Freeman. 1992. Rabbit aortic smooth muscle cells express inducible macrophage scavenger receptor messenger RNA that is absent from endothelial cells. J. Clin. Invest. 90:1450-1457.

28. Pitas, R. E. 1990. Expression of the acetyl low density lipoprotein receptor by rabbit fibroblasts and smooth muscle cells. Up-regulation by phorbol esters. J. Biol. Chem. 265:12722-12727.

29. Pitas, R. E., A. Friera, J. McGuire, and S. Dejager. 1992. Further characterization of the acetyl LDL (Scavenger) receptor expressed by rabbit smooth muscle cells and fibroblasts. Arterioscler. Thromb. 12:1235-1244.

30. Mahley, R. W. 1979. Dietary fat, cholesterol and accelerated atherosclerosis. Athero. Rev. 5:1-34

31. Clarkson, T. B., C. A. Shively, and K. W. Weingand. 1988. Animal models of diet induced atherosclerosis. Comp. Anim. Nutr. 6:56-82.

32. Kodama, T., M. Freemar, L. Rohrer, J. Zabrecky, P. Matsudaira, and M. Kreiger. 1990. Type I macrophage scavenger receptor contains $\alpha$-helical and collagen-like coiled coils. Nature (Lond.). 343:531-535.

33. Rohrer, L., M. Freeman, T. Kodama, M. Penman, and M. Kreiger. 1990 Coiled-coil fibrous domains mediate ligand binding by macrophage scavenger receptor type II. Nature (Lond.). 343:570-572.

34. Freeman, M., J. Ashkenas, D. J. G. Rees, D. M. Kinksley, N. G. Copeland N. A. Jenkins, and M. Kreiger. 1990 . An ancient, highly conserved family of cysteine-rich protein domains revealed by cloning type I and type II murine macrophage scavenger receptors. Proc. Natl. Acad. Sci. USA. 87:8810-8814.

35. Acton, S., D. Resnick, M. Freeman, Y. Ekkel, J. Ashkenas, and M. Krieger. 1993. The collagenous domains of macrophage scavenger receptors and comple- ment Clq mediate their similar, but not identical, binding specificities for polyanonic ligands. J. Biol. Chem. 268:3530-3537.

36. Penman, M., A. Lux, N. J. Freedman, L. Rohrer, Y. Ekkel, H. McKinstry, D. Resnick, and M. Krieger. 1991. The type I and type II bovine scavenger receptors expressed in Chinese hamster ovary cells are trimeric proteins with collagenous triple helical domains comprising noncovalently associated monomers and Cys ${ }^{83}$-disulfide-linked dimers. J. Biol. Chem. 266:23985-23993.

37. Via, D. P., E. S. Kempner, L. Pons, A. E. Fanslow, S. Vignale, L. C. Smith, A. M. Gotto, Jr., and H. A. Dresel. 1992. Mouse macrophage receptor for acetylated low density lipoprotein: Demonstration of a fully functional subunit in the membrane and purified receptor. Proc. Natl. Acad Sci. USA 89:6780-6784.

38. van Berkel, T. J. C., J. F. Nagelkerke, and J. K. Kruijt. 1981. The effect of $\mathrm{Ca} 2+$ and trifluoperazine on the processing of human acetylated low density lipoprotein by non-parenchymal liver cells. FEBS (Fed. Eur. Biochem. Soc.) Letters. 132:61-66.

39. Dresel, H. A., E. Friedrich, D. P. Via, G. Schettler, and H. Sinn. 1985. Characterization of binding sites for acetylated low density lipoprotein in the rat liver in vivo and in vitro. EMBO (Eur. Mol. Biol. Organ.) J. 4:1157-1162.

40. de Rijke, Y. B., and T. J. C. van Berkel. 1994. Rat liver kupffer and endothelial cells express different binding proteins for modified low density lipoproteins. Kupffer cells express a $95-\mathrm{kD}$ membrane protein as a specific binding site for oxidized low density lipoproteins. J. Biol. Chem. 269:824-827.

41. Nagelkerke, J. F., K. P. Barto, and T. J. C. van Berkel. 1983. In vivo and in vitro uptake and degradation of acetylated low density lipoprotein by rat liver endothelial, Kupffer, and parenchymal cells. J. Biol. Chem. 258:12221-12227

42. Pitas, R. E., J. Boyles, R. W. Mahley, and B. D. Montgomery. 1985. Uptake of chemically modified low density lipoproteins in vivo is mediated by specific endothelial cells. J. Cell Biol. 100:103-117.

43. Horiuchi, S., K. Takata, H. Maeda, and Y. Morino. 1985. Scavenger function of sinusoidal liver cells. Acetylated low-density lipoprotein is endocytosed via a route distinct from formaldehyde-treated serum albumin. J. Biol. Chem. 259:53-56.

44. van Berkel, T. J. C., Y. B. de Rijke, and J. K. Kruijt. 1991. Different fate in vivo of oxidatively modified low density lipoprotein and acetylated low density lipoprotein in rats. Recognition by various scavenger receptors on Kupffer and endothelial liver cells. J. Biol. Chem. 266:2282-2289.

45. Esbach, S., M. N. Pieters, J. Van der Boom, D. Schouten, M. N. Van der Heyde, P. J. M. Roholl, A. Brouwer, T. J. C. Van Berkel, and D. L. Knook. 1993. Visualization of the uptake and processing of oxidized low-density lipoproteins in human and rat liver. Hepatology. 18:537-545.

46. Mullis, K. B., and F. A. Faloona. 1987. Specific synthesis of DNA in vitro via a polymerase-catalyzed chain reaction. Methods Enzymol. 155:335-350.

47. Saiki, R. K., D. H. Gelfand, S. Stoffel, S. J. Scharf, R. Higuchi, G. T. Horn, K. B. Mullis, and H. A. Erlich. 1988. Primer-directed enzymatic amplification of DNA with a thermostable DNA polymerase. Science (Wash. DC). 239:487-491.

48. Sanger, F., S. Nicklen, and A. R. Coulson. 1977. DNA sequencing with chain terminating inhibitors. Proc. Natl. Acad. Sci. USA. 74:5463-5467.

49. Idzerda, R. L., R. R. Behringer, M. Theisen, J. I. Huggenvik, G. S. McKnight, and R. L. Brinster. 1989. Expression from the transferrin gene promoter in transgenic mice. Mol. Cell. Biol. 9:5154-5162.

50. Kozak, M. 1986. Bifunctional messenger RNAs in eukaryotes. Cell. 47:481-483

51. Kozak, M. 1989. The scanning model for translation: an update. J. Cell Biol. 108:229-241.

52. Brinster, R. L., and R. D. Palmiter. 1980. Introduction of genes into the germ lines of animals. Harvey Lect. 80:1-38.

53. Hogan, B., F. Costantini, and E. Lacy. 1986. Manipulating the Mouse Embryo: A Laboratory Manual. Cold Spring Harbor Laboratory. New York.

54. Southern, E. M. 1975. Detection of specific sequences among DNA frag ments separated by gel electrophoresis. J. Mol. Biol. 98:503-517.

55. Bradford, M. M. 1976. A rapid and sensitive method for the quantitation of microgram quantities of protein utilizing the principle of protein-dye binding Anal. Biochem. 72:248-254.

56. Lowry, O. H. N. J. Rosebrough, A. C. Farr, and R. J. Randall. 1951. Protein measurement with the Folin phenol reagent. J. Biol. Chem. 193:265-275.

57. Via, D. P., H. A. Dresel, and A. M. Gotto, Jr. 1986. Isolation and assay of the Ac-LDL receptor. Methods Enzymol. 129:216-226.

58. Havel, R. J., H. A. Eder, and J. H. Bragdon. 1955. The distribution and chemical composition of ultracentrifugally separated lipoproteins in human serum. J. Clin. Invest. 34:1345-1353.

59. McFarlane, A. S. 1958. Efficient trace-labelling of proteins with iodine. Nature (Lond.). 182:53.

60. Voyta, J. C., D. P. Via, C. E. Butterfield, and B. R. Zetter. 1984. Identification and isolation of endothelial cells based on their increased uptake of acetylatedlow density lipoprotein. J. Cell Biol. 99:2034-2040.

61. Paigen, B., A. Morrow, C. Bradon, D. Mitchell, and P. Holmes. 1985. Variation in susceptibility to atheroslcerosis among inbred strains of mice. Atherosclerosis. 57:65-73. 
62. Kieft, K. A., T. M. A. Bocan, and B. R. Krause. 1991. Rapid on-line determination of cholesterol distribution among plasma lipoproteins after highperformance gel-filtration chromatography. J. Lipid Res. 32:859-866.

63. Aalto-Setälä, K., C. L. Bisgaier, A. Ho, K. A. Kieft, M. G. Traber, H. J. Kayden, R. Ramakrishnan, A. Walsh, A. D. Essenburg, and J. L. Breslow. 1994 Intestinal expression of human apolipoprotein A-IV in transgenic mice fails to influence dietary lipid absorption of feeding behavior. J. Clin. Invest. 93:17761786.

64. Allain, C. C., L. S. Poon, C. S. G. Chan, W. Richmond, and P. C. Fu. 1974. Enzymatic determination of total serum cholesterol. Clin. Chem. 20:470475.

65. Hodis, H. N., D. W. Crawford, and A. Sevanian. 1991. Cholesterol feeding increases plasma and aortic tissue cholesterol oxide levels in parallel: further evidence for the role of cholesterol oxidation in atherosclerosis. Atherosclerosis. 89:117-126.

66. Hodis, H. N., A. Chauhan, S. Hashimoto, D. W. Crawford, and A. Sevanian. 1992. Probucol reduces plasma and aortic wall oxysterol levels in cholestero fed rabbits independently of its plasma cholesterol lowering effect. Atherosclerosis. 96:125-134.

67. Hodis, H. N., D. M. Kramsch, P. Avogaro, G. Bittolo-Bon, G. Cazzolato, J. H. Wang, H. Peterson, and A. Sevanian. 1994. Biochemical and cytotoxic characteristics of an in vivo circulating oxidized low density lipoprotein (LDL-). J. Lipid Res. 35:669-677.

68. Slayback, J. R. B., L. W. Y. Cheung, and R. P. Geyer. 1977. Quantitative extraction of microgram amounts of lipids from cultured human cells. Anal. Biochem. 83:372-384.

69. Christie, W. W. 1985. Rapid separation and quantification of lipid classes by high performance liquid chromatography and mass (light-scattering) detection J. Lipid Res. 26:507-512.

70. Beher, W. T., S. Strandnieks, G. J. Lin, and J. Sanfield. 1981. Rapid analysis of human fecal bile acids. Steroids. 38:281-295.

71. Nenseter, M. S., O. Gudmundsen, K. E. Malterud, T. Berg, and C. Drevon 1994. Effect of cholesterol feeding on the susceptibility of lipoproteins to oxidative modification. Biochim. Biophys. Acta. 1213:207-214.

72. Palinski, W., M. E. Rosenfeld, S. Ylä-Herttuala, G. C. Gurtner, S. S Socher, S. W. Butler, S. Parthasarathy, T. E. Carew, D. Steinberg, and J. Witztum. 1989. Low density lipoprotein undergoes oxidative modification in vivo. Proc Natl. Acad. Sci. USA. 86:1372-1376.

73. Palinski, W., V. A. Ord, A. S. Plump, J. L. Breslow, D. Steinberg, and J. L. Witztum. 1994. ApoE-deficient mice are a model of lipoprotein oxidatio in atherogenesis: demonstration of oxidation specific epitopes in lesions and high titers of autoantibodies to malondialdehyde-lysine in serum. Arterioscler. Thromb. 14:605-616.

74. Plump, A. S., J. D. Smith, T. Hayek, K. Aalto-Setälä, A. Walsh, J. G. Verstuyft, E. M. Rubin, and J. L. Breslow. 1992. Severe hypercholesterolemia and atherosclerosis in apolipoprotein E-deficient mice created by homologous recombination in ES cells. Cell. 71:343-353.
75. Bisgaier, C. L., M. V. Siebenkas, and K. J. Williams. 1989. Effects of apolipoprotein A-IV and A-I on the uptake of phospholipid liposomes by hepatocytes. J. Biol. Chem. 264:862-866.

76. Jackson, R. L. 1983. Lipoprotein lipase and hepatic lipase. The Enzymes. B. P. New York. 141-181.

77. Peterson, J., G. Bengtsson-Olivercrona, and T. Olivecrona. 1986. Mouse preheparin plasma contains high levels of hepatic lipase with low affinity for heparin. Biochim. Biophys. Acta. 878:65-70.

78. Tall, A. R., and D. M. Small. 1978. Plasma high density lipoproteins. N. Engl. J. Med. 299:1232-1236.

79. Eisenberg, S., J. R. Patsch, J. T. Sparrow, A. M. Gotto, Jr., and T. Olivecrona. 1979. Very low density lipoproteins. Removal of apolipoprotein CII and C-II-1 during lipolysis in vitro. J. Biol. Chem. 254: 12603-12608.

80. Schaefer, E. J., M. G. Wetzel, G. Bengtsson, R. O. Scow, H. B. Brewer, Jr., and T. Olivecrona. 1982. Transfer of human lymph chylomicron constituents to other lipoprotein density fractions during in vitro lipolysis. J. Lipid Res. 23:1259-1273.

81. Tam, S. P., and W. C. Breckenridge. 1983. Apolipoprotein and lipid distribution between vesicles and HDL-like particles formed during lipolysis of human very low density lipoproteins by perfused rat liver. J. Lipid Res. 24:13431357.

82. Agellon, L. B., A. Walsh, T. Hayek, P. Moulin, X. C. Jiang, S. A Shelanski, J. L. Breslow, and A. R. Tall. 1990. Reduced high density lipoprotein cholesteryl ester transfer protein transgenic mice. J. Biol. Chem. 260:1079610801.

83. Tall, A. R. 1993. Plasma cholesteryl ester transfer protein. J. Lipid Res. 34:1255-1274

84. Qiao, J.-H., P.-Z. Xie, M. C. Fishbein, J. Kreuzer, T. A. Drake, L. L. Demer, and A. J. Lusis. 1994. Pathology of atheromatous lesions in inbred and genetically engineered mice: Genetic determination of arterial calcification. Arterioscler. Thromb. 14:1480-1487.

85. Zhang, S. H., R. L. Reddick, J. A. Piedrahita, and N. Maeda. 1992. Spontaneous hypercholesterolemia and arterial lesions in mice lacking apolipoprotein E. Science (Wash. DC). 158:468-471.

86. Nakashima, Y., A. S. Plump, E. W. Raines, J. L. Breslow, and R. Ross 1994. ApoE-deficient mice develop lesions of all phases of athrosclerosis throughout the arterial tree. Arterioscler. Thromb. 14:133-140.

87. Reddick, R. L., S. H. Zhang, and N. Maeda. 1994. Atherosclerosis in mice lacking apoE: evaluation of lesional development and progression. Arterioscler. Thromb. 14:141-147.

88. Ishibashi, S., J. L. Goldstein, M. S. Brown, J. Herz, and D. K. Burns. 1994. Massive xanthomatosis and atherosclerosis in cholesterol-fed low density lipoprotein receptor-negative mice. J. Clin. Invest. 93:1885-1893.

89. Ishibashi, S., M. S. Brown, J. L. Goldstein, R. D. Gerard, R. E. Hammer, and J. Herz. 1993. Hypercholesterolemia in low density lipoprotein receptor knockout mice and its reversal by adenovirus-mediated gene delivery. J. Clin. Invest. 92:883-893. 